\title{
In defence of underlying representations: Latin rhotacism, French liaison, Romanian palatalization
}

DOI:

10.1515/probus-2017-0006

\section{Document Version}

Accepted author manuscript

Link to publication record in Manchester Research Explorer

\section{Citation for published version (APA):}

Bermúdez-Otero, R. (2018). In defence of underlying representations: Latin rhotacism, French liaison, Romanian palatalization. Probus, 30(2), 171-214. https://doi.org/10.1515/probus-2017-0006

\section{Published in:}

Probus

\section{Citing this paper}

Please note that where the full-text provided on Manchester Research Explorer is the Author Accepted Manuscript or Proof version this may differ from the final Published version. If citing, it is advised that you check and use the publisher's definitive version.

\section{General rights}

Copyright and moral rights for the publications made accessible in the Research Explorer are retained by the authors and/or other copyright owners and it is a condition of accessing publications that users recognise and abide by the legal requirements associated with these rights.

\section{Takedown policy}

If you believe that this document breaches copyright please refer to the University of Manchester's Takedown Procedures [http://man.ac.uk/04Y6Bo] or contact uml.scholarlycommunications@manchester.ac.uk providing relevant details, so we can investigate your claim.

\section{OPEN ACCESS}




\title{
In defence of underlying representations:
}

\section{Latin rhotacism, French liaison, Romanian palatalization}

\author{
Ricardo Bermúdez-Otero \\ University of Manchester
}

30 April 2018

To appear in Probus 30:2 (2018)

\begin{abstract}
The surface realization of a linguistic expression can often be predicted from the form of paradigmatically related items that are not contained within it: in Latin, the nominative singular of a noun can often be inferred from the genitive; in French, the final consonant of a prenominal masculine adjective in liaison can typically be predicted from the feminine; in Romanian, the plural form of a noun determines whether its stem will exhibit palatalization before the derivational suffix /-ist/. Such instances of phonological paradigmatic dependency without containment have been claimed to challenge cyclic models of the morphosyntax-phonology interface. In this article, however, they are shown to be established indirectly through the acquisition of underlying representations. This approach correctly predicts that phonological paradigmatic dependencies are never systematically extended to new items if they involve suppletive allomorphy rather than regular alternation, whilst those surface phonological properties of derivatives that are under strict phonotactic control evade paradigmatic dependency on the inflectional forms of their bases. Theories relying on surface-to-surface computation fail to recover these empirical predictions because they are inherently nonmodular, positing generalizations that promiscuously mix phonological, morphosyntactic, and lexical information. Underlying representations therefore remain indispensable as a means of establishing a necessary modular demarcation between regular phonology and suppletive allomorphy.
\end{abstract}

\section{Keywords}

Cyclic containment, lexical conservatism, modularity, paradigmatic dependence, predictability, regular phonology, suppletive allomorphy, surface-to-surface computation, underlying representation.

\section{Introduction}

What are the relative roles of syntagmatic structure and paradigmatic relations in determining the form of linguistic expressions (Saussure 1916: $2^{\text {nd }}$ part, ch. V)? This is surely one of the most basic questions confronting any theory of morphophonology. Though otherwise diverging widely from one another, all 
cyclic approaches to the morphosyntax-phonology interface like SPE (Chomsky \& Halle 1968), Lexical Phonology (Kiparsky 1982), Distributed Morphology (Halle \& Marantz 1993, Embick 2010), Cophonology Theory (Orgun 1996, Inkelas 1998) and Stratal Optimality Theory (Kiparsky 2000, 2015; Bermúdez-Otero 2010, 2018) agree on the same answer: paradigmatic information from distributions and alternations is crucial to the acquisition of grammatical regularities and lexical representations (Wunderlich 2003: 28); but, when assigning a surface realization to a linguistic expression, the grammar refers solely to its syntagmatic structure and to the underlying representations of its constituents (Bailyn \& Nevins 2008: 241).

This conceptually simple approach to the relationship between syntagms and paradigms makes precise predictions about morphologically conditioned phonology. These predictions include the following:

\section{Cyclic Containment (Bermúdez-Otero 2018: 103)}

In cases of morphosyntactically induced phonological opacity, a linguistic expression inherits its opaque phonological properties from a constituent defining an immediate cyclic subdomain.

A clear example of this phenomenon may be found in the failure of the English deverbal noun accòmmodátion to bear pretonic secondary stress on its initial syllable (cf. monomorphemic àbracadábra): the verb stem accómmodàte- is an immediate constituent of the noun accommodát-ion, and the latter cyclically inherits the foot-head on the second syllable of the former.

Natural languages, however, often exhibit phonological paradigmatic dependencies between expressions that do not stand in relationships of containment with each other. In Romanian, for example, adding the derivational suffix /-ist/ to a noun stem ending in $/ \mathrm{k} / \mathrm{or} / \mathrm{g} /$ triggers palatalization of the velar plosive to $[\mathrm{t}]$ or [dz] if, and only if, the plural form of the noun also exhibits palatalization caused by the inflectional marker/-i/ or /-e/ (Steriade 2008; see Section 5 below): ${ }^{1}$

a.

b. SG fók

PL fókuri

\section{base}

SG sting $\Lambda$
PL stindzi 'left (hand)'

'fire'

\section{derivative}

*stingíst

stindzist

*fotfist

fokíst 'locomotive engineer'

Yet, in cyclic models of the morphosyntax-phonology interface, the derived phonological properties of the inflected plural form [stindzi] can play no role in the generation of denominal [stindzíst] because the former is not a constituent of the latter. Phonological paradigmatic dependencies without containment have therefore been argued to pose a direct challenge to cyclic theories of grammar (Steriade 1999, 2008, 2012, 2013; Steriade \& Yanovich 2015).

\footnotetext{
1 Abbreviations of grammatical categories, whether in glosses or elsewhere, follow the Leipzig Glossing Rules.
} 
According to these arguments, paradigmatic dependencies without containment prove the need for computational mechanisms that relate surface forms to one another directly. Grammatical frameworks incorporating mechanisms of surface-to-surface computation include output-output correspondence in Optimality Theory (Kenstowicz 1996, Benua 1997) and item-and-process theories of morphology driven by surface principal parts (Albright 2002, 2008: §7.3; Blevins 2006; Stump \& Finkel 2013: 17, 51-2). In its most radical versions, this line of thought has resulted in proposals to abolish underlying representations altogether, on the grounds that their functions can be adequately discharged by independently motivated mechanisms of surface-to-surface computation (Burzio 1996, Cole \& Hualde 1998, Allen \& Becker 2015; cf. Hyman 2018).

Nonetheless, the classic approach to syntagms and paradigms outlined in the opening paragraph offers a different line of attack on phonological paradigmatic dependencies without containment. As adumbrated by Bermúdez-Otero (2018: 101, 114-115) in a similar connection, a surface form can indirectly determine the phonological behaviour of a morphologically related item by providing the learner with cues to the underlying representation of a constituent contained within both expressions. In the Romanian case in (2), for example, plural noun forms like [st'́ndzi] and [fókuri] may reflect some underlying property of their respective stems which in turn controls the incidence of palatalization before derivational suffixes (see Section 5 for a concrete proposal). Cyclic theories of grammar thus entail the following hypothesis:

(3) Phonological paradigmatic dependencies without containment are established indirectly through the acquisition of underlying representations.

This article seeks first to ascertain the precise empirical content of proposition (3) and then to corroborate it by testing it against three instances of phonological paradigmatic dependency without containment that have figured prominently in the literature: the levelling of rhotacism alternations in Classical Latin (Albright 2002: ch. 4), the occurrence of split-base forms in French adjectival liaison (Steriade 1999), and the facts of Romanian palatalization introduced above (Steriade 2008).

Section 2 shows that the precise empirical content of proposition (3) depends on the extent of the powers granted to morphology and phonology within a particular grammatical framework. Notably, proposition (3) can easily escape falsification if phonology is allowed to enact item- or constructionspecific generalizations (Inkelas \& Zoll 2007, Pater 2009). Theories that countenance morphemespecific phonology make it easy to reduce vastly heterogeneous sets of alternations to single underliers because the phonological generalizations motivated by one alternation need not hold true for other alternations in the same language. In contrast, proposition (3) proves far more restrictive when embedded within a strictly modular grammatical framework. The Four-Hypothesis Programme of Bermúdez-Otero (2012: 44), for example, enforces a sharp modular demarcation between morphology and phonology by forbidding morphology from altering the phonological content of morphs ('Morph Integrity') and by banning item- or construction-specific phonology ('Indirect Reference'). This results in a clean distinction between cases of suppletive allomorphy (in which surface alternants derive from separate underliers) and cases of regular phonological alternation (in which surface alternants derive 
from a common underlier through the application of regular phonology). Once this distinction is established, proposition (3) turns out to make a strong empirical prediction about paradigm extension:

(4) Phonological paradigmatic dependencies can be systematically extended to new items if they involve regular alternation, but not if they involve suppletive allomorphy.

As it turns out, theories of surface-to-surface computation fail to recover prediction (4) because they are inherently nonmodular: they rely on devices that project one surface form from another by reference to a mixture of phonological, morphosyntactic, and lexical information.

Section 3 shows that prediction (4) explains well-known facts about the levelling of rhotacism alternations in Classical Latin. In Preclassical Latin, the application of rhotacism created an $[\mathrm{s}] \sim[\mathrm{r}]$ alternation that was later levelled to $[\mathrm{r}]$ in third-declension nonneuter polysyllables like NOM.SG bonōs $~$ GEN.SG bonōis 'honour': in Classical Latin this became bonor $\sim$ bonōris, whilst the alternation was retained in neuters like opus $\sim$ operis 'work' (Weiss 2009: 152). Albright (2002: ch. 4) explains the change from bonōs to bonor by noting that, for nonneuter polysyllables, learners of Preclassical Latin could attach greater confidence to a surface-to-surface rule inferring NOM.SG forms in [or] from GEN.SG forms in [o: ris] than to one inferring nominatives in [o:s]. In this analysis, NOM.SG forms are paradigmatically dependent on GEN.SG forms, even though genitives are not contained within nominatives. However, Albright's account incorrectly predicts that neuter polysyllables like NOM.SG acer $\sim$ GEN.SG aceris 'maple' should have changed to *acus aceris, since a rule inferring NOM.SG forms in [us] for neuter polysyllables with genitives in [eris] enjoyed greater confidence than one inferring nominatives in [er]. In contrast, the absence of innovative NOM.SG forms like *acus follows automatically from proposition (3) once it is understood that the [us] [eris] alternation in opus operis, though created by neogrammarian change, had become suppletive in Classical Latin.

Section 4 turns to the case of French adjectival liaison. Items like premier 'first', sot 'silly', and certain 'certain' participate in a productive pattern of nonnormative liaison whereby masculine forms preceding a vowel-initial head-noun exhibit the final vowel of masculine citation forms followed by the final consonant of feminine forms (Steriade 1999): ${ }^{2}$

\begin{tabular}{|c|c|c|c|c|}
\hline & & M.SG citation & F.SG & M.SG liaison (e.g. __ffriend') \\
\hline premier & 'first' & рьәтје & рьәтјєь & рьәтјек аті \\
\hline sot & ‘silly’ & so & sot & sot ami \\
\hline certain & 'certain' & sest $\tilde{\varepsilon}$ & sebten & sebstz̃n ami \\
\hline
\end{tabular}

Steriade analyses this pattern as an instance of 'lexical conservatism': the final consonant of the masculine liaison form is licensed by surface-to-surface correspondence with the feminine form, whilst the preceding vowel is required to match its correspondent in the citation form of the masculine. However, this account incorrectly predicts that the grammar has the power to effect the same

\footnotetext{
2 Here, nonnormative (Steriade's term) means 'departing from the literary norm codified in prescriptive works such as Grevisse and Gosse (2011)'.
} 
productive blend of phonological properties in suppletive paradigms like M.SG nouveau [nuvo] F.SG nouvelle [nuvel], yielding the liaison form *[nuvol] instead of nouvel [nuvel]. Not only are forms like *[nuvol] entirely unattested among suppletive adjectives in French, but there are also no reported instances in natural language of the productive and automatic blending of submorphic phonological properties from different cells in suppletive paradigms. In contrast, proposition (3) explains why apparent blending occurs in (5) but not in suppletive paradigms like that of nouveau: the forms in (5) are actually derived from single underliers by means of regular phonological processes governing consonantal latency, mid-vowel tenseness, and vowel nasalization, whereas nouveau has two listed underlying allomorphs.

Section 5 turns to the Romanian evidence presented in (2). Steriade (2008) interprets it as an instance of 'inflection dependence', whereby the phonological shape of a derivative paradigmatically depends on the surface phonological properties of an inflectional form of its base. This challenge to Cyclic Containment crucially rests on the claim that the palatalization of / $\mathrm{k}, \mathrm{g} / \mathrm{to}$ [tg, $\left.\mathrm{d}_{3}\right]$ before /i, e/ is phonologically derived. This claim, however, underplays the role of morphology in the alternation, which is confined to a specific set of morphologically defined environments. Noting a parallel between the incidence of palatalization and the occurrence of the thematic element/-ur-/ in neuter nouns, I propose an alternative account in which the mapping of root-final $/ \mathrm{k}, \mathrm{g} /$ onto $[\mathrm{t}, \mathrm{d}]$ is triggered by the presence of an underlying thematic morph consisting of a palatalizing autosegment. Romanian palatalization thus contrasts with the alternation between unstressed [o] and stressed [oa] in the same language. The application of the latter in the inflectional paradigms of simple nouns shows that it involves true phonotactic restrictions that override underlying specifications: in the native vocabulary, for example, the diphthong [oa] is forbidden in unstressed syllables. In a modular cyclic architecture, the fact that the $[\mathrm{o}] \sim[\mathrm{oa}]$ alternation is under phonotactic rather than morphological control correctly predicts that it will not display apparent inflection dependence in derivatives. Steriade's account, however, fails to recover this prediction because her surface-to-surface constraints do not distinguish between morphologically and phonotactically controlled phonological features.

Section 6 draws out the implications of these three case studies. The facts of Latin rhotacism and of French liaison confirm that, as predicted in (4), phonological paradigmatic dependencies without containment can be systematically extended to new items when they involve regular phonology, but not when they involve suppletive allomorphy. In turn, the evidence of Romanian shows that true phonotactic generalizations are immune to inflection dependence, which is a specific type of paradigmatic dependence without containment. All together, the evidence of Latin, French, and Romanian demonstrates the need to distinguish regular phonological alternation from instances of suppletive allomorphy and of morphologically controlled distribution. Existing theories of surface-tosurface computation sacrifice this distinction by positing generalizations that promiscuously mix phonological, morphological, and lexical information. Concomitantly, these surface-to-surface frameworks replace the distinction between regular phonology and suppletive allomorphy with criteria such as degrees of confidence (Albright 2002: 40-41) or degrees of salience (Steriade 1999: 264, 2008: 341). But these substitutes do not make the cut in the right place: as shown by the case of Latin opus operis and acer aceris, for example, patterns of suppletive allomorphy fail to be systematically extended even when they enjoy high confidence scores. In contrast, modular cyclic frameworks enshrine 
the necessary distinction between regular alternation and suppletive allomorphy by defining a level of representation that abstracts away from the former but not the latter: the underlying representation. Calls to abolish underlying representations should therefore be resisted for as long as surface-to-surface frameworks remain unable to recover the distinction between regular phonology and suppletive allomorphy.

\section{Modular restrictions on the extension of paradigmatic dependencies}

The assertion that phonological paradigmatic dependencies without containment are enforced indirectly through the acquisition of underlying representations (3) does no more that codify common descriptive practice in all the frameworks that espouse the approach to syntagms and paradigms laid out in the opening paragraph of Section 1. This can be illustrated with a simple example. In King Alfred's Early West Saxon dialect, oblique forms like the DAT.SG enable one to predict the NOM/ACC.PL realization of a neuter $a$-stem noun with a disyllabic NOM/ACC.SG form beginning a light stressed syllable: as shown in (6), the stem, highlighted in bold, will display the same number of syllables in the NOM/ACC.PL as in the DAT.SG, and stems ending in obstruent+sonorant clusters retain the NOM/ACC.PL marker/-u/ which otherwise apocopates under metrically defined conditions (Bermúdez-Otero \& Hogg 2003: §3.1). This cannot be a cyclic effect, as the DAT.SG is not contained with the NOM/ACC.PL. Rather, the connection between the two forms lies in the fact that they both faithfully reflect the underlying properties of the stem, which are obscured in unmarked NOM/ACC.SG forms by a regular process of vowel insertion into word-final rising-sonority clusters.

(6)

$\begin{array}{lllll} & \text { NOM/ACC.SG } & \text { DAT.SG } & \text { NOM/ACC.PL } & \text { stem UR } \\ \text { 'troop' } & \text { we.rod } & \text { we.ro.de } & \text { we.rod } & \text { /werod-/ } \\ \text { 'water' } & \text { wæ.ter } & \text { wæt.re } & \text { wæt.ru } & \text { /wætr-/ }\end{array}$

The paradigmatic dependence of the NOM/ACC.PL on oblique forms is therefore routed through the acquisition of the underlying representation of the stem that they both share:

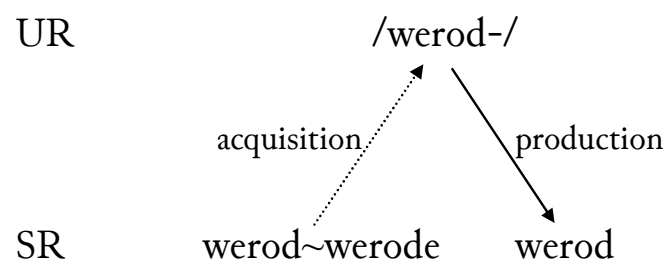

It should be noted that cyclic analyses of paradigmatic dependencies with containment are not essentially different: they too involve an indirect relationship mediated by shared underlying structure. As we saw in Section 1, for example, the location of pretonic secondary stress in English deverbal nouns like accòmmodátion and clàssificátion can be predicted from the location of primary stress in unmarked finite forms of their bases like the 1SG.PRS: I accómmodàte, I clássify. Yet, obviously, the 1SG.PRS form is not contained within the relevant deverbal noun, nor does the latter inherit its metrical contour from 
the former; rather, both derive from the same verb stem, which does not itself surface. It just so happens that the verb stem is morphophonologically (but not morphosyntactically) coextensive with the 1SG.PRS form and defines a domain for the cyclic application of phonology.

Drawing on diagram (7), we can now formulate a schema for the extension of phonological paradigmatic dependencies to new items in cyclic frameworks. In the most general terms, a phonological paradigmatic dependency exists when the surface form of an expression [A] makes it possible to predict the surface realization of a morphosyntactically related expression $[\mathrm{B}] .^{3}$ In a cyclic framework, this entails that the learner sets up a shared underlier /X/ from which both $[\mathrm{A}]$ and $[\mathrm{B}]$ are derived through the application of regular phonology, hereafter represented as $\mathcal{P}$.

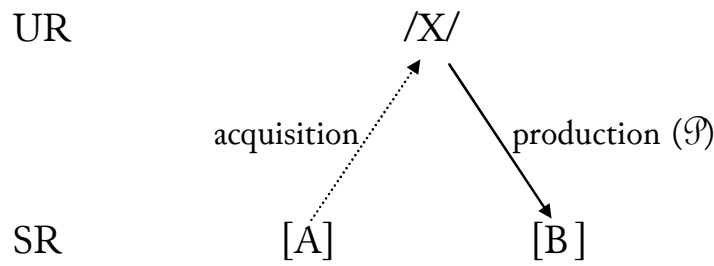

The dependency between $[\mathrm{A}]$ and $[\mathrm{B}]$ can undergo extension when the learner encounters a new surface expression $\left[\mathrm{A}^{\prime}\right]$ sharing relevant properties with $[\mathrm{A}]$. Extension takes place if the learner sets up an underlier $/ \mathrm{X}^{\prime} /$ such that an alternation $\left[\mathrm{A}^{\prime}\right] \sim\left[\mathrm{B}^{\prime}\right]$ is derived from $/ \mathrm{X}^{\prime} /$ by means of the same regular phonology that derives $[\mathrm{A}] \sim[\mathrm{B}]$ from $/ \mathrm{X} /$.

UR

SR

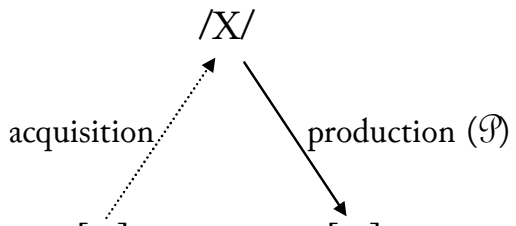

$[\mathrm{A}]$
[B]

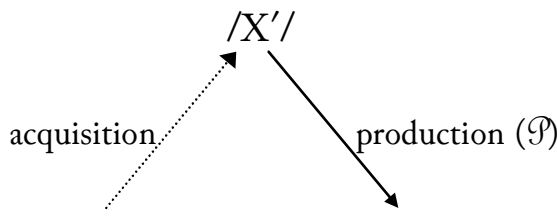

$\left[\mathrm{A}^{\prime}\right]$
$\left[\mathrm{B}^{\prime}\right]$

In cases of suppletive allomorphy, however, the surface alternants derive from separate underliers:

\footnotetext{
3 As Steriade's French example in (5) shows, the predictor in a relationship of paradigmatic dependence need not be a single expression, but may consist of a set comprising several members. In what follows, therefore, $[\mathrm{A}]$ should be interpreted loosely as referring to one or more forms. This point is strongly emphasized both in work within the tradition of $S P E$ (Kenstowicz \& Kisseberth 1977: 32-33) and in word-and-paradigm theories of morphology relying on principal parts (Stump \& Finkel 2013). Albright's (2002: 11, 2008: 152) surface-to-surface model is relatively exceptional in advancing a Single Surface Base Hypothesis, but see Bowers (2015: ch. 3) for empirical evidence that paradigmatic dependencies involving multiple predictors can be diachronically stable.
} 
(10)

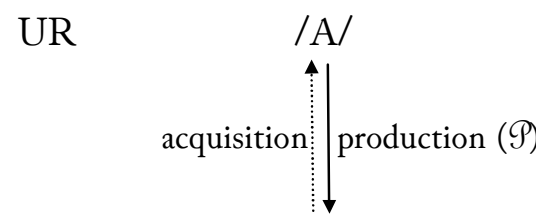

SR

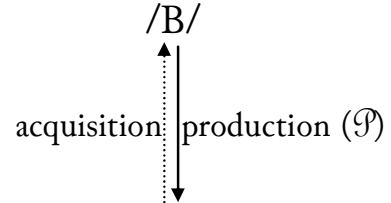

[B]

In cases like (10), a strictly modular framework like the Four-Hypothesis Programme (Bermúdez-Otero 2012: 44) predicts, as per (4), that the alternation between [A] and [B] cannot be systematically extended to a set of new items $\left[\mathrm{A}^{\prime}\right],\left[\mathrm{A}^{\prime \prime}\right]$, etc. First, extension cannot take place by phonological means because, ex bypothesi, the language does not have regular phonological processes capable of deriving alternations like $[\mathrm{A}] \sim[\mathrm{B}],\left[\mathrm{A}^{\prime}\right] \sim\left[\mathrm{B}^{\prime}\right]$, and $\left[\mathrm{A}^{\prime \prime}\right] \sim\left[\mathrm{B}^{\prime \prime}\right]$ from single underliers. In practice, nonmodular theories can easily evade this restriction by resorting to ad boc cophonologies or indexed constraints (Inkelas \& Zoll 2007, Pater 2009): see Section 1. However, the Four-Hypothesis Programme explicit forbids this expedient through its Indirect Reference provision:

\section{Indirect Reference (after Bermúdez-Otero 2012: 77)}

A phonological constraint may not refer to syntactic, morphological, or lexical information unless to require alignment between designated prosodic units and the exponents of designated word- or phrase-syntactic nodes.

At the same time, extension cannot take place by morphological means as long as morphology is bound by Morph Integrity:

Morph Integrity (after Bermúdez-Otero 2012: 50)

Morphological operations do not alter the phonological content of morphs.

Morph Integrity bans process morphology altogether (see Stonham 1994, Trommer 2011, and the further references listed in Bermúdez-Otero 2018: 123; cf. Anderson 1992, Inkelas 2012). In consequence, Morph Integrity deprives morphology of the power to systematically generate new allomorphs $/ \mathrm{B}^{\prime} /$, / $\mathrm{B}^{\prime \prime} /$, etc.

Many of the cyclic frameworks listed in Section 1 openly violate both Indirect Reference and Morph Integrity. A salient example of such modularity violations is the use of readjustment rules in Distributed Morphology (Embick \& Halle 2005; cf. Bermúdez-Otero 2012: 79-81, Haugen 2016). Work like Trommer (2015), however, demonstrates that it is possible for cyclic grammatical architectures to attain a very high standard of modularity (see Scheer 2011 for germane discussion). Theories of surface-to-surface computation, in contrast, are inherently nonmodular because they establish relationships of correspondence between surface phonological strings on the basis of morphosyntactic and lexical criteria. This may be illustrated with two examples that will become relevant in later sections: (13) sets out one of Albright's (2002: 66) rules for the NOM.SG form of polysyllabic nonneuter nouns of the third declension in Classical Latin (see Section 3); (14) reproduces 
one of the constraints that Steriade (1999:259) uses to project masculine liaison forms from the citation forms of French adjectives (see Section 4).

$$
[\mathrm{o:ris}]_{\mathrm{GEN} . \mathrm{SG}} \rightarrow[\mathrm{or}]_{\mathrm{NOM} . \mathrm{SG}} /[\mathrm{X}]_{\text {polysyl,-neut___ } \#}
$$

\section{LEX(V,gender)}

If $\mathrm{T} \mu$ (the realization of morpheme $\mu$ under evaluation) and some $\mathrm{L} \mu$ (some lexically stored realization of $\mu$ ) have the same gender features, then the accented $V$ in $T \mu$ has a correspondent $\mathrm{V}^{\prime}$ in $\mathrm{L} \mu$ and is identical featurally and stresswise to $\mathrm{V}^{\prime}$.

In both cases, phonological and morphosyntactic features mix promiscuously. It is this inherent lack of modularity that prevents theories of surface-to-surface computation from recovering prediction (4).

\section{The levelling of Latin rhotacism}

Shortly before the earliest written records, Latin underwent a regular sound change of rhotacism whereby intervocalic /s/, in all likelihood realized as [z], became [r]. As a result, Preclassical Latin exhibited a pervasive set of alternations between $[\mathrm{s}]$ and $[\mathrm{r}]$. By the classical period, this alternation was systematically levelled to $[\mathrm{r}]$ in the inflectional paradigms of masculine and feminine polysyllabic nouns of the third declension $(15, \mathrm{a})$, whilst neuters and monosyllables remained alternating $(15, \mathrm{~b}-\mathrm{c})$ : see Weiss (2009: 152). In this section, I focus exclusively on the contrast between nonneuter and neuter polysyllables $(15, \mathrm{a}-\mathrm{b})$.

\begin{tabular}{llclll}
\multicolumn{2}{c}{ Preclassical } & \multicolumn{2}{c}{ Classical } & \\
NOM.SG & GEN.SG & NOM.SG & GEN.SG & \\
\cline { 1 - 3 } hono:s & hono:ris & honor & hono:ris & 'honour' & M \\
opus & operis & no change & 'work' & N \\
korpus & korporis & no change & 'body' & N \\
mo:s & mo:ris & no change & 'custom' & M
\end{tabular}

Why was there systematic levelling in the masculines and feminines, but no levelling in the neuters? Albright (2002: ch. 4) proposes an answer that relies on surface-to-surface computation. His account consists of two main elements. First, Albright argues that Latin learners selected a single cell in nominal paradigms as the surface base from which to infer the forms occupying the other cells (see note 3). Oblique forms proved more informative than NOM.SG realizations because the latter were subject to a wide range of morphological and phonological neutralizations: to take one small example, in the third declension the contrast between root-final / k/ and /kt/ in F.GEN.SG [lu:kis] 'light' vs [noktis] 'night' was phonologically neutralized to $[\mathrm{k}]$ in the NOM.SG forms [luks] and [noks]. Albright therefore settles on the GEN.SG as the surface base of Latin nominal paradigms. Secondly, Albright proposes that learners 
adopt surface-to-surface rules taking the surface base as input and projecting the other inflected forms from it. A rule is adopted if it enjoys a higher adjusted confidence score that the alternatives. The rule's adjusted confidence score is a function of its scope (the number of items meeting its structural description) and its hits (the number of forms it correctly derives): see Albright (2002: 40-41) and Albright \& Hayes (2003: 126-127) for details. In essence, the best rules have wide scope (applying to large numbers of items) and high accuracy (yielding correct outcomes for the items in their scope).

Albright demonstrates that, in Preclassical Latin, the rule predicting the alternating pattern of nonneuter polysyllables like honōs bonōris $(15, \mathrm{a})$, with etymological root-final /s/, attracted lower confidence than a competing rule generating the nonalternating behaviour exemplified by items like soror $\sim$ sorōis 'sister.F.NOM GEN.SG', with etymological root-final /r/:

$$
\text { confidence score }^{4} \quad \text { Preclassical example }
$$

\begin{tabular}{|c|c|c|}
\hline $\begin{array}{l}{[\mathrm{O}: \mathrm{ris}]_{\mathrm{GEN} . \mathrm{SG}} \rightarrow[\mathrm{or}]_{\mathrm{NOM} . \mathrm{SG}} /[\mathrm{X}]_{\text {polysyl,-neut___\# }}} \\
{[\text { o:ris }]}\end{array}$ & $\begin{array}{l}0.723 \\
0.611\end{array}$ & $\begin{array}{l}\text { soror } \sim \text { soro: ris } \\
\text { hono:s } \sim \text { hono:ris }\end{array}$ \\
\hline
\end{tabular}

According to Albright, this caused the soror soröris pattern to replace the bonōs bonōris pattern. Albright further observes that, in contrast, rules generating $[\mathrm{s}] \sim[\mathrm{r}]$ alternations enjoyed the highest confidence scores in the case of neuter nouns:

confidence score Preclassical example

$$
\begin{aligned}
& {[\text { eris }]_{\mathrm{GEN} . \mathrm{SG}} \rightarrow[\mathrm{us}]_{\mathrm{NOM} . \mathrm{SG}} /[\mathrm{X}]_{\text {polysyl,+neut___ \# }} 0.643} \\
& {[\text { eris }]_{\mathrm{GEN} . S G} \rightarrow[\mathrm{er}]_{\mathrm{NOM} . \mathrm{SG}} /[\mathrm{X}]_{\text {polysyl__ }} \# \quad 0.374} \\
& {[\text { oris }]_{\mathrm{GEN} . \mathrm{SG}} \rightarrow[\mathrm{us}]_{\mathrm{NOM} . \mathrm{SG}} /[\mathrm{X}]_{\text {polysyl, }+ \text { neut___ }} \# 0.545} \\
& {[\text { Vris }]_{\mathrm{GEN} . \mathrm{SG}} \rightarrow[\mathrm{Vr}]_{\mathrm{NOM} . \mathrm{SG}} /[\mathrm{X}]_{\text {neut___ }} \# 0.198}
\end{aligned}
$$

opus operis 'work' $\mathrm{N}$ aker akeris 'maple' $\mathrm{N}^{5}$ korpus korporis 'body' $\mathrm{N}$ marmor marmoris 'marble' $\mathrm{N}$

\footnotetext{
4 I report the scores as recalculated by Rodber (2008). This does not materially affect the discussion.
}

Donca Steriade (p.c.) draws my attention to the fact that most tree names are feminine in Latin. However, this generalization sustains many exceptions. Crucially, third-declension tree names in -er -ěris are systematically neuter: e.g. acer 'maple', sìler 'osier', and sūber 'cork-tree'.

(i) Acer, eiusdem fere amplitudinis, operum elegantia ac subtilitate citro secundum[N.NOM.SG, not *secunda]. 'The maple, of nearly the same size [as the lime], is inferior to the citrus in the elegance and fineness of the woodwork.' (Plin. Nat. 16.26)

(ii) ut molle[N.NOM.SG, not *mollis] siler lentaeque genestae 'like the soft osier and the flexible broom-shrubs' (Verg. G. 2.12)

In both passages, the context shows unambiguously that the neuter noun refers to the whole tree, not just to the wood: e.g. Pliny compares the size of the maple tree to that of the lime (eiusdem fere amplitudinis). Priscian $\left(6^{\text {th }} \mathrm{C} A D\right)$ reports that Maurus Servius Honoratus $\left(4^{\text {th }}-5^{\text {th }} \mathrm{C}\right.$ AD) treated acer as feminine, but this was a very late departure from classical usage as attested in Pliny the Elder $\left(1^{\text {st }} \mathrm{C} A D\right)$. 
This, Albright argues, explains why neuters like opus operis and corpus corporis resisted levelling.

Albright's account, however, incurs a serious problem. If the pattern enforced by the rule enjoying the highest confidence score among masculine and feminine nouns was extended to all the items within its scope, then by parity of reasoning the same phenomenon should be observed among neuter nouns. As shown in (17), the best rules for neuters according to Albright's theory were the following:

$$
\begin{aligned}
& {[\text { eris }]_{\mathrm{GEN} . \mathrm{SG}} \rightarrow[\mathrm{us}]_{\mathrm{NOM} . \mathrm{SG}} /[\mathrm{X}]_{\text {polysyl,+neut___ }} \text { \# }} \\
& {[\text { oris }]_{\mathrm{GEN} . \mathrm{SG}} \rightarrow[\mathrm{us}]_{\mathrm{NOM} . \mathrm{SG}} /[\mathrm{X}]_{\text {polysyl,+neut___ }}}
\end{aligned}
$$

The allomorphy of opus operis should accordingly have been extended to neuter polysyllables with GEN.SG forms ending in [eris], and the allomorphy of corpus corporis should have been extended to neuter polysyllables with GEN.SG forms ending in [oris]. Changes of the following sort are therefore predicted:

$$
\begin{aligned}
& \text { Preclassical Classical } \\
& \text { aker akeris }>\quad \text { *akus akeris 'maple' N } \\
& \text { marmor marmoris }>\quad \text { *marmus } \sim \text { marmoris 'marble' } \mathrm{N}
\end{aligned}
$$

This prediction is incorrect: innovative N.NOM.SG forms like *acus and * marmus do not occur. We can be fairly confident that the absence of such forms is not an accident of the philological record: in the $1^{\text {st }} \mathrm{C} \mathrm{AD}$, Quintilian (Inst. 1.6.22) fulminated against innovative NOM.SG variants of neuter nouns like ebur eboris 'ivory' and rōbur röboris 'oak, strength', but the target of his prescriptive condemnation was the levelling of [o] to the nominative, yielding ebor and robor; we can be sure that Quintilian would have been just as scathing had he encountered *ebus, but this form is completely unattested. ${ }^{6}$

\begin{tabular}{|c|c|c|c|}
\hline & Preclassical & & Classical \\
\hline UR & /hono:s-/ & $>$ & /hono:r-/ \\
\hline SR & hono:s hono: ris & & honor hono: ris \\
\hline
\end{tabular}

Modular cyclic frameworks do not incur the *acus problem. In such frameworks, the changes that did occur can easily be described as involving the restructuring of underlying representations (though cf. Kiparsky 1997 for a different approach):

Crucially, the shortening of underlying /o: before word-final / $\mathrm{r}$ / in the new NOM.SG form involves regular phonology. In contrast, the paradigm extensions in (19) are correctly ruled out by theorem (4) because the allomorphy of opus operis and corpus corporis was synchronically suppletive in Classical

\footnotetext{
6 In contrast, NOM.SG rōbus is indeed attested, but as an older form in Cato the Elder (Agr. 17.1, c. 160 BC), then echoed by Columella (Rust. 2.6.1, c. 60-65 AD). It is therefore likely that rōbus rōboris > rōbur rōboris was a relatively isolated case of levelling of the rhotacism alternation among neuters (Weiss 2009: 152). Accordingly, the occurrence of rōbus is not an instance of the incorrect empirical prediction shown in (19).
} 
Latin: it was therefore absolutely impossible for restructuring to give rise to a new underlier surfacing as *acus aceris.

The first key observation is that Classical Latin did not have a synchronically valid phonological process capable of deriving the $[\mathrm{u}] \sim[\mathrm{e}]$ alternation of opus operis from a single underlying /V/. Prehistorically, all short unstressed vowels had neutralized to [e] before /r/. Neuter nouns like tempus temporis 'time' had once complied with this pattern, as shown by the cognate adverb temperi 'in a timely manner'. However, levelling of a back vowel from the NOM.SG replaced prehistoric GEN.SG ${ }^{\dagger}$ [temperis] with temporis (Weiss 2009: 118, 239, 307). At this point, the phonology was reorganized so that the pattern of corpus corporis and tempus $\sim$ temporis became the regular phonological outcome of an underlying back vowel, whilst the pattern of cinis $\sim$ cineris 'ashes' $(\mathrm{M} / \mathrm{F})$ remained the regular phonological outcome of an underlying front vowel (see Weiss 2009: 152, note 20). Nonlevelled alternations like opus operis became allomorphic and so, by theorem (4), ineligible for extension to items like acer aceris.

The second key observation is that, by the classical period, intervocalic rhotacism itself survives only as a process of phonologically driven allomorph selection (see Kiparsky 1997 for evidence), but no longer constitutes an automatic alternation (Wetzels 1981). Roberts (2012: 80-81) provides a long list of synchronic exceptions including:

- /s/ from etymological /s:/, as in causa 'cause';

- irregular dissimilatory blocking, as in miser 'wretched' (cf. ${ }^{\dagger}$ swesōr > soror without blocking); and - loanwords like basis 'pedestal' (from Greek).

On these grounds, Roberts (2012: 92) reaches a qualified agreement with Baldi's (1994) conclusion that "there is no synchronic rhotacism in [Classical] Latin."

In sum, the modular cyclic framework outlined in Section 2 correctly predicts the fact that the allomorphy of Latin neuter polysyllables like opus operis is not systematically extended to other neuters like acer aceris. Unattested ${ }^{*}$ acus aceris cannot arise through the restructuring of underlying representations because the synchronic phonology of Classical Latin is unable to derive the allomorphs [akus] and [aker-] from a single underlier. Similarly, the allomorphy of opus operis cannot be systematically extended by morphological computation because Morph Integrity (12) prevents the morphology from generating new suppletive stems like */akus/ by rule. Albright's theory of surface-tosurface computation fails to recover this correct prediction because it relies on rampantly nonmodular mechanisms: see again the rules in (16) and (17). Crucially, the paradigmatic pattern exhibited by opus operis enjoys high confidence scores despite being allomorphic: the fact that it fails to be extended thus proves that confidence scores are no substitute for the distinction between regular alternation and suppletive allomorphy, as enshrined in the underlying level of representation of modular cyclic frameworks.

\section{French adjectival liaison}

\subsection{The problem of split-base formations in French adjectival liaison}

Steriade (1999: §4-§5) adduces French adjectival liaison as evidence against Cyclic Containment (1). The goal of her own account is to generate the masculine singular form of a French adjective in liaison, 
i.e. when immediately followed by a head noun beginning with a vowel: e.g. mon petit ami [mõ.pə.ti.ta.mi] 'my.M.SG little.M.SG friend.M.SG'. To this end she posits a set of optimality-theoretic LEX constraints which work by consulting the surface realizations of the adjective in nonliaison masculine singular environments and in the feminine singular; these surface realizations are assumed to be stored in memory owing to their relatively high token frequency. Examples of the paradigms under discussion are provided in (21). ${ }^{7}$

\begin{tabular}{|c|c|c|c|c|c|c|}
\hline & joli & 'pretty' & 3oli & zoli & zoli & \\
\hline & lisse & 'smooth' & lis & lis & lis & \\
\hline b. & petit & 'little' & pati & patit & patit & \\
\hline c. & grand & 'tall' & gва̃ & gва̃d & gьãt & \\
\hline & gros & 'big' & gво & gвоs & gвоz & \\
\hline d. & franc & 'frank' & fusã & fъã $\int$ & fuã & \\
\hline e. & nouveau & 'new’ & nuvo & nuvel & nuvel & \\
\hline & vieux & 'old' & vjø & vjej & vjej & \\
\hline f. & premier & 'first' & рьәтје & рьәтјєь & $\left\{\begin{array}{l}\text { рьәтјєь } \\
\text { рьәтјеь }\end{array}\right.$ & $\begin{array}{l}\text { normative } \\
\text { nonnormative }\end{array}$ \\
\hline & sot & ‘silly’ & so & sot & $\left\{\begin{array}{l}s J t \\
s o t\end{array}\right.$ & $\begin{array}{l}\text { normative } \\
\text { nonnormative }\end{array}$ \\
\hline & certain & 'certain’ & sebt $\tilde{\varepsilon}$ & sebten & $\left\{\begin{array}{l}\text { sesten } \\
\text { sest } \tilde{\varepsilon} n\end{array}\right.$ & $\begin{array}{l}\text { normative } \\
\text { nonnormative }\end{array}$ \\
\hline
\end{tabular}

In Steriade's account, a masculine liaison candidate exhibiting a surface property $p$ satisfies the LEX constraint on $p$ if $p$ is present in either (or both) of the masculine and feminine citation forms. Through interaction with other constraints, this enables the rise of split-base formations that blend phonological properties of both citation forms. As instances of split-base formation, Steriade highlights nonnormative liaison realizations like [рьәтјев], [sot], and [sєьtг̃n]: in her analysis, for example, [рьәтјек] сорies its final [в] from the feminine output form [рьәтјєь], whilst the preceding [e] originates in [рьәmje], which is the surface realization of the masculine in nonliaison contexts. This explanation is incompatible with Cyclic Containment insofar as the feminine is not a morphosyntactic constituent of the masculine liaison form. The challenge to cyclic frameworks is all the more pressing because, in French dialects where adjectival liaison remains active, ${ }^{8}$ the productive pattern for adjectives like PREMIER, SOT, and CERTAIN is nonnormative split-base liaison: see Tranel (1981: 108-9).

\footnotetext{
7 Throughout the following discussion I ignore the plural, which only figures peripherally in Steriade's analysis. For reasons of space I also set aside adjectives whose feminine singular forms end in consonant clusters. On both issues, see Wetzels (2002: 298-301) for analyses compatible with the approach I shall take here.

$8 \quad$ Adjectival liaison is in decline in contemporary French (Durand 2014: §12.5.2.3), as is the frequency of adjective-noun orders. Concomitantly, there are dialects in which adjectival liaison has become lexicalized or has disappeared altogether
} 
It is eminently plausible that both the masculine and the feminine citation forms of a French adjective influence its realization in liaison. It by no means follows, however, that this influence is best described by means of constraints evaluating direct relationships between surface forms. Rather, in line with proposition (3), we may alternatively hypothesize that surface tokens in nonliaison environments exert their influence on the liaison form through the process whereby learners construct underlying representations. As required by the approach to syntagms and paradigms set out at the start of Section 1 , once underliers have been established, derivations make no reference to paradigmatic information and Cyclic Containment is fully respected.

An account of French adjectival liaison centred on underlying representation discovery makes the following crucial predictions. First, the surface realization of an adjective in liaison can combine properties of the masculine and feminine citation forms only if the learner has set up a single underlying representation incorporating features of both:

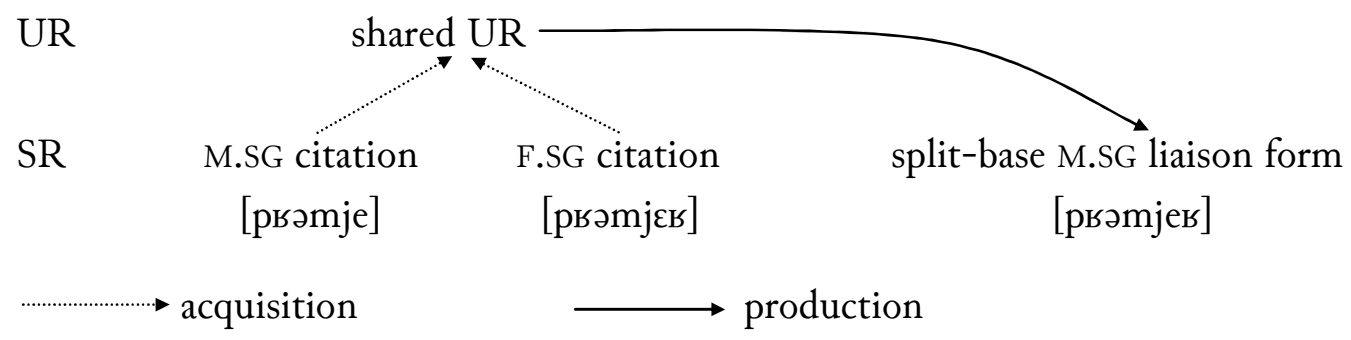

In turn, this is possible only if the learner's grammar includes phonological processes that correctly derive the masculine and feminine alternants from a shared single underlier. Split-base formations are thus predicted to arise only through the mediation of productive phonological generalizations. In contrast, blending is predicted to be impossible in cases of suppletion, in which there is no shared single underlier:

a. UR

SR

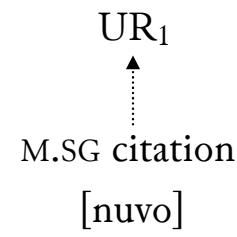

b. UR

SR single-base M.SG liaison form [fьã ]

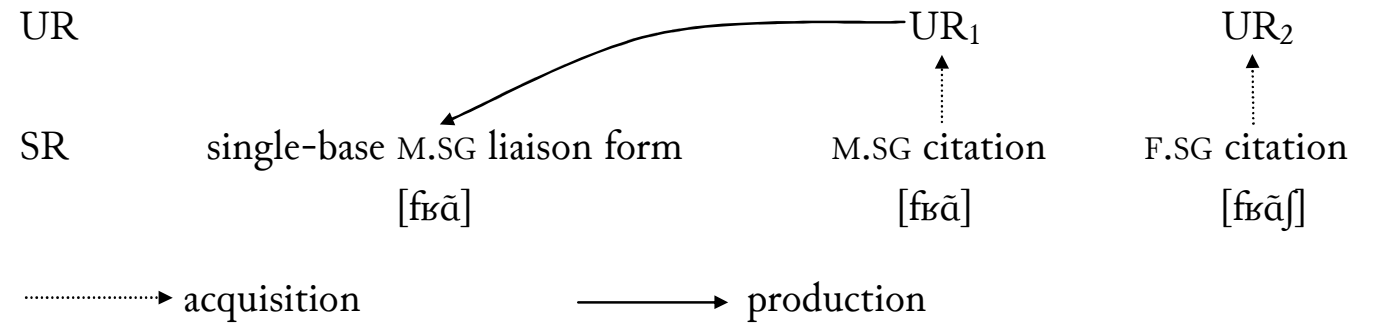

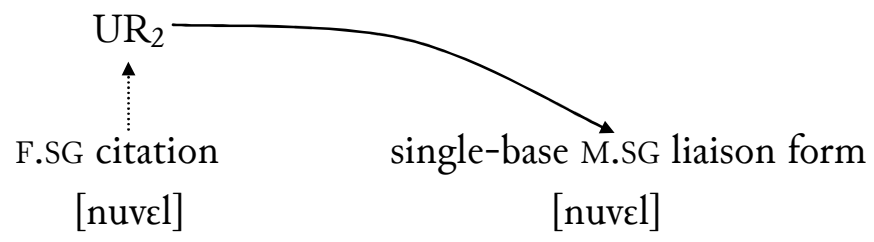

[nuvel]

This resulting prediction is stated in (24).

(Tranel 1981: 270-2). My discussion is confined to those conservative dialects in which it remains-or until recently remained-productive. 
Split-base formations that systematically blend phonological properties drawn from two different alternants do not arise when those alternants are suppletive.

Cyclic Containment therefore compels us to analyse the nonnormative split-base liaison forms in $(21, \mathrm{f})$ as being phonologically derived from single underliers shared by the masculine and feminine citation forms. In turn, this entails that productive rules in the synchronic phonology of present-day French must control the following alternations: (i) the consonant zero alternations in PREMIER, SOT, and CERTAIN; (ii) the vowel tenseness alternations in PREMIER and SOT; and (iii) the vowel nasality alternation in CERTAIN. I now proceed to show that all of these predictions are correct.

\subsection{The grammar of latent consonants}

For the consonant zero alternations in PREMIER, SOT, and CERTAIN, I adopt the classical autosegmental analysis of latent consonants (Tranel 1995) as implemented by Wetzels (1987, 2002). In this analysis, consonants that do not alternate are underlyingly fixed; consonants that alternate nonsuppletively are underlyingly latent. A fixed consonant is underlyingly anchored to a skeletal unit; a latent consonant floats in the underlying representation, and surfaces only if it is able to link up to a skeletal unit during the derivation. ${ }^{9}$ Thus, the surface forms of adjectives like JOLI, LISSE, and PETIT (21a,b) derive from underliers such as the following: ${ }^{10}$

\begin{tabular}{|c|c|c|}
\hline 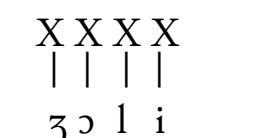 & 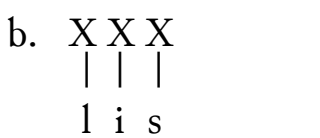 & 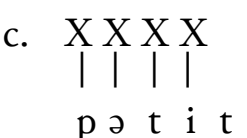 \\
\hline nonalternating & nonalternating & alternating \\
\hline V-final & C-final & latent C \\
\hline
\end{tabular}

Following Wetzels (1987: 296), I further assume that, when the lexicon does not store a suppletive feminine form, agreement with feminine targets is marked by means of an inflectional suffix

\footnotetext{
$9 \quad$ For our current purposes Smolensky \& Goldrick's (2016) account of liaison within the framework of Gradient Symbolic Computation is just a variant of the classical autosegmental approach, differing from it only in that the representational defectiveness of latent consonants is conceived of as a gradient rather than categorical property. Beyond this, however, certain caveats are in order. French liaison is a vastly complex and varied phenomenon: see Côté (2011) for a general survey. My proposals here bear only on those aspects of adjectival liaison that are most directly relevant to the assessment of Steriade's surface-to-surface account. I make no claims about the extent to which autosegmental representations may be involved in other types of liaison, nor do I assume that a single mechanism is necessarily at work in all types (cf. e.g. Morin \& Kaye 1982, Côté 2010). I also set aside phenomena such as b-aspiré and liaison sans enchaînement; the latter, in particular, has been shown not to arise in conversational speech (Durand 2014: §12.5.2.2). Finally, I believe that the skeletal slot that hosts the latent consonant of a masculine adjective in prenominal liaison is an exponent of a syntactic configuration and not predictable from pure prosody (see Côté 2010: $§ 4$ for general discussion); but this question is not crucial here.

10 Below I shall occasionally use parentheses to notate underlying latent consonants: thus I shall write /lis/ for $(25, \mathrm{~b})$ but $/$ pati $(\mathrm{t}) /$ for $(25, \mathrm{c})$.
} 
consisting of a bare skeletal slot. As a result, no final consonant in a feminine form ever remains floating in the output of the word level. This accounts for the fact that there are no liaison alternations in feminine forms.

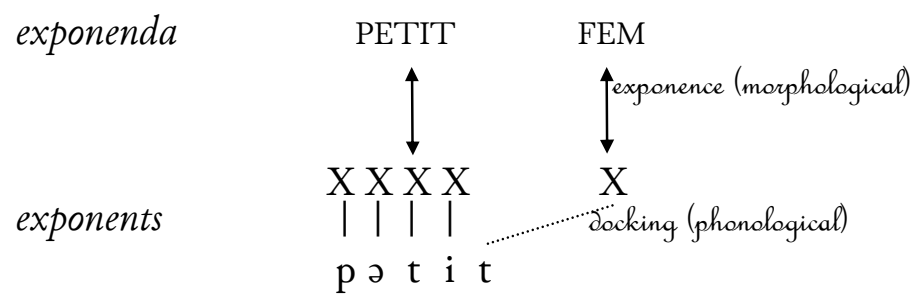

The autosegmental approach receives powerful support from the observation that it is possible to insert a pause or intonational phrase boundary before a latent consonant surfacing through liaison (Morin 1986: 198, Tranel 1990). In contrast, an intonational phrase boundary cannot ever precede a word-final linked consonant, whether the latter is underlyingly fixed $(25, b)$ or it is underlyingly latent but becomes linked by the word level through feminine inflection (26).

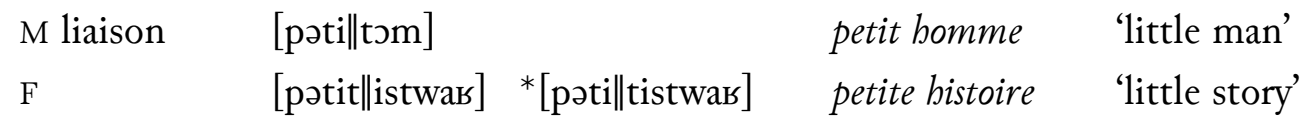

This reflects the different prosodic status of floating and linked consonants in the input to the phrase level: the generalization is that intonational phrase boundaries may not fall inside strings prosodified together in the input to the phrase level (Wetzels 2002: 301).

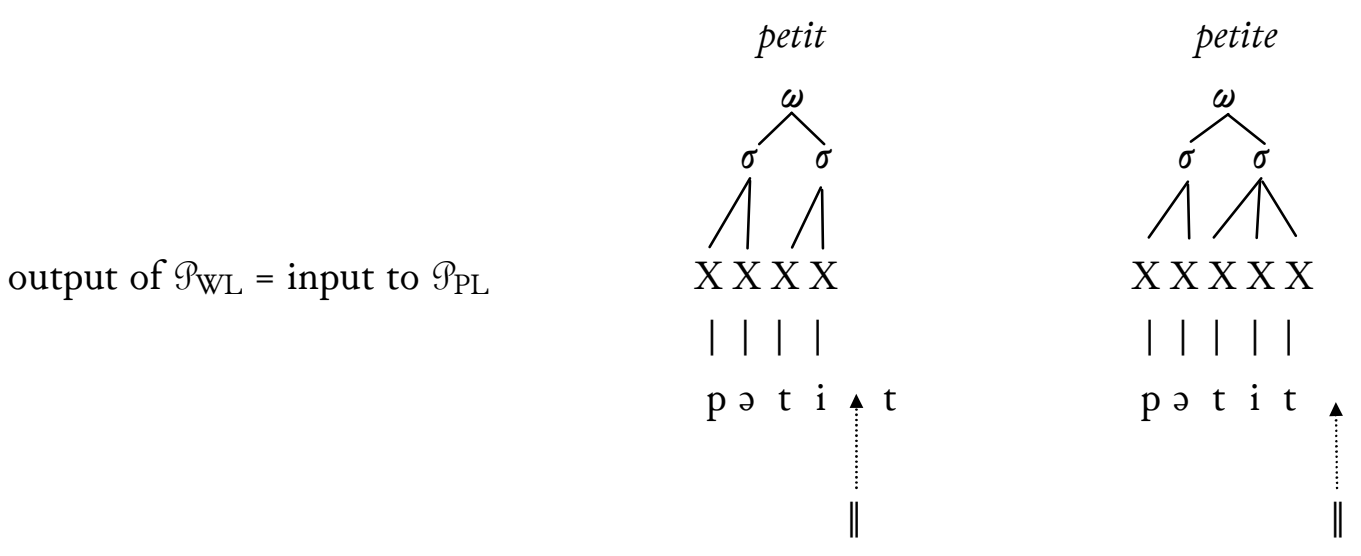

In present-day French, latent consonants are drawn from a relatively narrow set, the most frequent being /z, n, t/ (Durand \& Lyche 2008: 58). For this reason, French speakers do not interpret all consonant $\sim$ zero alternations in adjectives as reflecting the presence of an underlying latent segment. The alternation between []$]$ and $[\varnothing]$ in the citation forms of FRANC $(21, d)$, for example, is analysed as suppletive: the corresponding lexical entry is shown in (29). The diacritic $\varsigma$ represents a lexically stored instruction to perform syntactically driven allomorph selection during exponence: /fuã $f /$ is inserted only if the exponendum is feminine, and /frã// behaves as the elsewhere exponent. Thus, because /fira $/$ has no latent consonant, it does not alternate in liaison. 


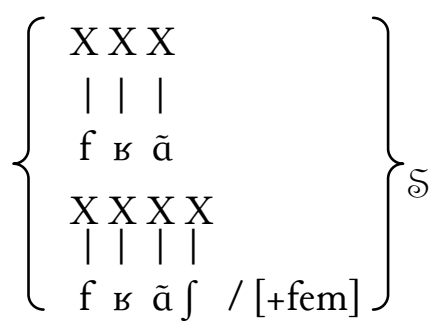

As noted by Lamarche (1996: 149), the behaviour of FRANC speaks strongly against nonmodular theories like those of Tranel (1996) and Perlmutter (1998), in which a phonological constraint driving liaison (say, ONSET) interacts in parallel with a morphosyntactic constraint requiring gender agreement (say, CONCORD): the ranking ONSET $\gg$ CONCORD incorrectly predicts liaison realizations like franc

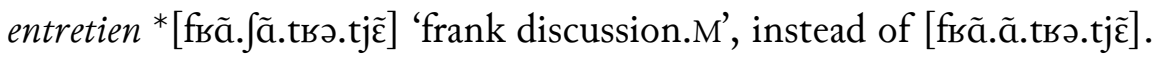

Similarly, the alternation between [nuvo] and [nuvel] $(21, \mathrm{e})$ is undeniably suppletive, and so cannot reflect the presence of a latent consonant in a shared underlier. In this case, the fact that the allomorph /nuvel/ appears both in feminine and in masculine liaison contexts is derived simply by preventing /nuvo/ from realizing [+fem] exponenda and otherwise deferring allomorph selection until the phonology (see Bermúdez-Otero 2012: 52 and references therein). This is indicated by the diacritic $\mathcal{P}$ in lexical entry (30), which instructs morphology to insert both allomorphs (as long as syntactic subcategorization requirements are met) and to defer allomorph selection to the phonology.

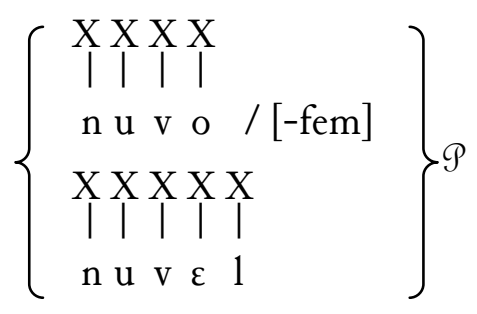

In autosegmental terms, moreover, the allomorph /nuvel/ must end in a fixed consonant, as shown in (30), since this $/ 1 /$ is able to surface before feminine nouns that do not begin with a vowel. This inference automatically explains Morin's (1986: 198) and Tranel's (1990) observation that the liaison form of NOUVEAU, unlike that of PETIT, rejects the insertion of an intonational phrase boundary before its final consonant: cf. (27) and (31).

$$
\begin{aligned}
& \text { M liason [nuvel\|elefã] *[nuve\|llelefã] nouvel éléphant 'new elephant bull' } \\
& \text { F [nuvell|elefãt] *[nuve\|lelefãt] nouvelle éléphante 'new elephant cow' }
\end{aligned}
$$

Moreover, French does not have a productive phonological process devoicing word-final consonants. In consequence, the alternation between the masculine liaison form [grãt] and the feminine form [grãd] in $(21, \mathrm{c})$ must be suppletive too. Yet, since the masculine alternates between [grãt] in liaison and [grã] elsewhere, its final /t/ must be underlyingly latent: i.e. /grã (t)/. 


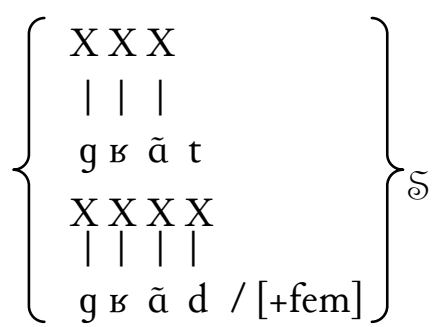

Once again, the autosegmental approach leads to exact predictions about intonational phrase boundaries: the masculine liaison form of GRAND (33) behaves like that of PETIT (27) and unlike that of NOUVEAU (31).

$$
\begin{aligned}
& \text { M liaison [grã\|tami] } \\
& \text { F [gьãd\|amitje] *[gьã } \| \text { damitje] grande amitié 'great friendship' } \\
& \text { grand ami 'great friend' }
\end{aligned}
$$

\begin{tabular}{|c|c|c|c|c|c|}
\hline grand & 'tall' & gва̃ & gкãd & gва̃ & \\
\hline cf. froid & 'cold' & fвwa & frwad & fuwa & (Morin 2005: 12) \\
\hline chaud & 'hot' & do & jod & do & (Plénat 2008: §2.1) \\
\hline gros & 'big' & gьо & gвоs & gьоz & \\
\hline cf. épais & 'thick' & epe & epes & epe & (Féry 2004: 34-35) \\
\hline roux & 'red-haired' & ви & bus & ви & (Jacques Durand: p.c. \\
\hline
\end{tabular}

In addition, the suppletive analysis of the voicing alternations in GRAND and GROS $(21, \mathrm{c})$ correctly entails that these alternations are not productively extended to other adjectives: ${ }^{11}$

\subsection{The loi de position and the phonotactics of vowel nasalization}

Having dealt with consonant $\sim$ zero alternations in adjectival liaison, we are now ready to account for the productivity of the nonnormative split-base patterns in $(21, \mathrm{f})$. To be explained is the fact that the liaison form [рьәтјев] combines features of both citation forms: the vowel [e] of masculine [рьәтје] and the final consonant of feminine [рьәтјєь]. Why do speakers generate such novel alternants in liaison, as reported by Tranel (1981: 108-9), whilst they reject * [ jot] and *[epez] (34)? As shown in (22) and (23), an account driven by underlying representation discovery predicts that the mixture of properties in [рьәтјев] саn arise only because the learner sets up a single shared underlier for the masculine and feminine citation forms, and this, in turn, is possible only because there are productive phonological generalizations mapping this single underlier to the surface alternants known to the learner.

\footnotetext{
11 Steriade's (1999: 254) grammar incorrectly generates * [epez] and * [suz] as the liaison forms of ÉPAIS and ROUX. This problem can be rectified by promoting the IDENT-voice constraint so as to forbid voicing alternations in liaison, whilst treating [gьãt] and [gьоz] as members of the set of surface forms stored in memory owing to their high token frequency.
} 
The productive phonological generalization at work in the paradigm of premier is the wellknown loi de position: simplifying somewhat, this states that the unmarked or default realization of mid vowels is tense (mid-high) in open syllables and lax (mid-low) in closed syllables (Valdman 1972, Tranel 1988). In (35) I show that the loi de position applies at the word level. I use data from Midi French, where the loi de position sustains no exceptions (Durand and Eychenne 2014: §3.1); the relevant facts are identical in other dialects. Crucially, linked consonants syllabified in coda position at the word level trigger closed syllable laxing, and this component of the loi de position is counterbled by phrase-level resyllabification when the following word begins with a vowel. In contrast, latent consonants do not trigger closed syllable laxing because they remain floating in the output of the word level and so do not behave like codas. ${ }^{12}$

Loi de position in Midi French (after Durand and Eychenne 2014: §3.1)

underlier

Now consider a learner who has been exposed to the citation forms [рьәтје] and [рьәтјєь]. Faced with the $[\mathrm{e}] \sim[\varepsilon]$ and $[\varnothing] \sim[\mathrm{B}]$ alternations, she may take them to be morphologically controlled, and so she may subsume the adjective under the pattern of NOUVEAU $(21, \mathrm{e})$. This will result in a disjunctive underlier with /рьәтјєь/ as the allomorph unmarked for gender: i.e. $\left\{/ \text { рьәтје } /{ }^{[-\mathrm{fem}]}, / \text { рьәтјєь/ }\right\}^{\mathscr{S}}$. Such a suppletive representation will yield single-base [рьәтјєь] in liaison: cf. (30). Alternatively, the learner may interpret the $[\varnothing] \sim[\mathrm{B}]$ alternation as reflecting an underlying latent consonant that becomes linked in the feminine by suffixation of a skeletal slot (26) and, concomitantly, she may interpret the $[\mathrm{e}] \sim[\varepsilon]$ alternation as derived by the loi de position from an underlying /E/ unspecified for tenseness, as in (35). In that case, there will be a single shared underlier

\footnotetext{
12 Word-level prosodification also places an $\omega$-boundary between productive prefixes and stems: this is responsible for contrasts like prestance [рьвs.ta ${ }^{\mathrm{N}}$. .sə] 'fine bearing' and pré-scolaire [рье.sko.le..ə] 'pre-school' (Durand and Eychenne 2014: $\S 3.2$; see also Hannahs 1995).
} 
after the pattern of PETIT $(25, \mathrm{c})$. The shared underlier analysis is shown in $(36, \mathrm{a})$. By regular morphology and phonology $(36, b)$, the split-base form [рьәтјев] will emerge in liaison. ${ }^{13}$

(36) a. underlier

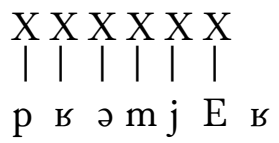

b.

\begin{tabular}{clc} 
M citation & F citation & M liaison \\
\hline рьәтјЕ(в) & рьәтјЕ(в) & рьәтјЕ(в) \\
- & рьәтјЕь & - \\
.рьә.тје.(в) & .рьә.тјєь. & .рьә.тје.(в)
\end{tabular}

phrase level liaison

.рьә.mje.

.рьә.тје.ьа.mi.

Without further stipulation, this analysis also derives the judgements about intonational breaks provided by Plénat (2008: §3.1), who reports that normative single-base liaison with [рьәтјєь] requires a break to follow the $[\mathrm{ь}]$, whereas nonnormative split-base liaison with [рьәтјек] requires a break to precede the $[\mathrm{b}]$ :

single-base liaison

split-base liaison
'I have a first one-an elephant'

J'en ai un [рьәтјєь\|] éléphant

J'en ai un [рьәтје $\left.\|_{\mathrm{s}}\right]$ éléphant

This is because single-base liaison involves a suppletive allomorph ending in a fixed consonant, like nouvel éléphant (31), whereas split-base liaison involves a floating consonant in the input to the phrase level, as in petit bomme (27) and grand ami (33).

The case of CERTAIN is closely analogous. Single-base liaison in [sesten] arises when the learner

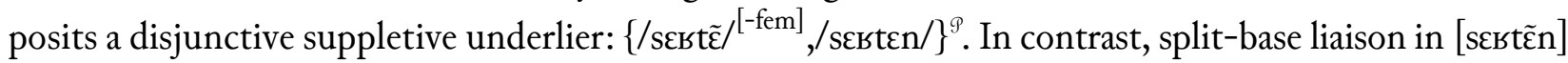
occurs if the learner subsumes the masculine and feminine citation forms under the single underlier /sest $\tilde{\varepsilon}(\mathrm{n}) /$ and derives the surface alternation by means of the phonotactic constraint systematically banning [+nasal] vowels in rhymes closed by nasal consonants:

\footnotetext{
13 Observe that this analysis does not require that [e] and $[\varepsilon]$ should be in perfect complementary distribution within word-level domains; all that is required is that the loi de position should be synchronically active as a blank-filling phonological process applying to underlying /E/ (Tranel 1988: 95). As it happens, underlying underspecification for tenseness works for both the $[\mathrm{e}] \sim[\varepsilon]$ and $[\mathrm{o}] \sim[\mathrm{J}]$ alternations, which are highly pervasive; other options do not work for the normative variety, in which the tenseness contrast undergoes neutralization in different environments for front and back vowels (Valdman 1972: 477). Thus, [e] cannot be checked by a fixed consonant, but $[\varepsilon]$ is permitted in open syllables:

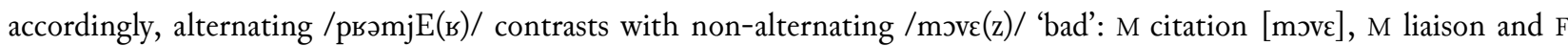
[movez]. Conversely, [o] is allowed to be checked by a fixed consonant, but [ $[0]$ is forbidden in word-final open syllables: in consequence, alternating /sO(t)/ 'silly' $(21, \mathrm{f})$ contrasts with non-alternating /.o ( $\mathrm{t}) /$ 'high': $\mathrm{M}$ citation [.o], $\mathrm{M}$ liaison and $\mathrm{F}$ [.ot].
} 


\begin{tabular}{|c|c|c|c|c|}
\hline \multirow[b]{2}{*}{ underlier } & & M citation & F citation & M liaison \\
\hline & & seьt $\tilde{\varepsilon}(\mathrm{n})$ & seьt $\tilde{\varepsilon}(\mathrm{n})$ & seьt $\tilde{\varepsilon}(\mathrm{n})$ \\
\hline \multirow[t]{2}{*}{ word level } & F-suffixation & - & sebtẽ & - \\
\hline & $\left.{ }^{*} \mathrm{~V}^{[+ \text {nas }]} \mathrm{C}^{[+ \text {nas }]}{ }_{\sigma}\right]$ & 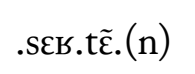 & .sعв.tعn. & 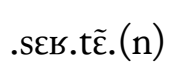 \\
\hline phrase level & liaison & 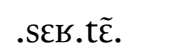 & - & 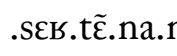 \\
\hline
\end{tabular}

\subsection{Underlying representation discovery gives rise to variation}

An analysis of split-base liaison centred on the discovery of underlying representations enjoys another salient advantage. We have seen that setting up underliers for French adjectives necessarily involves deneutralization (Nevins \& Vaux 2008). The underlying opposition between latent and fixed consonants, as in /prti(t)/ vs /lis/, is neutralized morphologically in the feminine by the suffixation process shown in (26). The underlying opposition between latent consonants and / $\varnothing /$, as in /pati $(\mathrm{t}) / \mathrm{vs}$ /zoli/, is neutralized phonologically in masculine citation forms through the failure of floating consonants to dock. When setting up underliers, the learner seeks to undo these neutralizations; but, since her linguistic experience provides her with widely different amounts of information for different adjectives, her choice of underliers will show lexical variation, and so will the liaison patterns generated by the grammar.

This phenomenon has been recognized by many scholars: e.g. Bonami and Boyé (2003: §2.2), Féry (2004: 26), Plénat (2008: §2.1). Crucially, our analysis predicts that lexical irregularity will extend to adjectives capable of displaying split-base liaison like PREMIER and CERTAIN, even though the splitbase pattern is currently dominant. Strikingly, this prediction proves accurate: Féry's (2004: 34-35) informants, for example, displayed strongly divergent preferences for DERNIER and LÉGER, favouring normative single-base liaison for the former and nonnormative split-base liaison for the latter:

\begin{tabular}{|c|c|c|c|c|c|}
\hline & & M.SG citation & F.SG citation & M.SG liaison & \\
\hline dernier & 'last' & desnje & dєsnјєs & dєьnјєь & (single-base) \\
\hline léger & 'light' & leze & lezes & lеzеь & (split-base) \\
\hline
\end{tabular}

Féry suspects that her findings reflect a bias towards vowel harmony. This may be so: the data in (39) may thus reflect competition between the loi de position and vowel harmony in northern dialects (Durand \& Lyche 2004, Nguyen \& Fagyal 2008: 23). However, there is another consideration that carries greater weight: DERNIER has higher token frequency in prenominal environments than LÉGER, and this enhances the survival chances of the more conservative liaison realization (Wetzels p.c.).

In sum, an account of French adjectival liaison centred on the discovery of underlying representations explains why split-base liaison is possible only when the masculine and feminine citation forms are related by synchronically productive phonological processes: see (36) and (38). The analysis also predicts the fact that the incidence of split-base liaison is lexically specific (39). Through its connection with the autosegmental approach to latent consonants (Wetzels 2002), it further yields a 
strikingly accurate and entirely nonstipulative characterization of the behaviour of single-base and splitbase liaison forms before intonational phrase boundaries (37). But, most importantly for our current purposes, this analysis impeccably complies with Cyclic Containment (1).

\subsection{Problems for surface-to-surface computation: the suppletive blending pathology}

We may now compare our account with one based on LEX constraints. To explain the variation shown in $(21, \mathrm{f})$, Steriade (1999: 261) posits two antagonistic LEX constraints: LEXP- $\forall$ requires the liaison form to be fully and completely identical to a single citation form, whereas LEX(V́,gender) just requires the liaison form to copy the accented vowel of the citation form of the same gender (the masculine). The ranking LEXP- $\forall \gg \operatorname{LEX}\left(V^{\prime}\right.$,gender) generates consistently normative single-base liaison; the opposite ranking LEX(V́,gender) $\gg$ LEXP- $\forall$ predicts liaison to be uniformly nonnormative and splitbase. In the case of PREMIER, for example, LEX(V',gender) requires the masculine liaison form to copy the accented vowel of the masculine citation form [рьәmje], whilst leaving it free to avoid hiatus by also copying the final consonant of feminine [рьәтјєь]. ${ }^{14}$

It becomes immediately apparent, however, that the ranking LEX(V́,gender) $\gg$ LEXP- $\forall$ predicts that French dialects with [рьәтјек] will choose * [nuvol] as the liaison form for NOUVEAU. Yet * [nuvol] is completely unattested and entirely unacceptable. To avoid the problem, Steriade posits another LEX constraint, LEXP- $\forall_{\text {loose }}$, which requires the liaison form to be fully and completely identical to a single citation form except in respect of nonsalient properties. Steriade (1999: 264) asserts that the $[\varepsilon] \sim[\mathrm{e}]$ alternation in [рьәтјєь] [рьәтјек] is nonsalient because mid-vowel tenseness is largely phonologically predictable by the loi de position, whereas the $[\varepsilon] \sim[\mathrm{o}]$ alternation in [nuvel] $\sim^{*}[$ nuvol] would be too salient because it would not be bridged by a productive phonological generalization. Thus, with LEXP- $\forall_{\text {loose }}$ ranked above LEX(V́,gender), *[nuvol] loses to [nuvel].

This solution is open to two objections. First, it is unclear how LEXP- $\forall_{\text {loose }}$ gains access to the necessary information about salient differences: crucially, reference to distance in acoustic space will not be enough, since the relevant notion of salience derives from systemic patterns of contrast. The underlier discovery approach, in contrast, deduces the same result from first principles, without repackaging phonological predictability as lack of salience: the learner can conflate two surface forms under a single underlying representation only when their alternations are predictable by phonological rule (22).

Secondly, the crucial ranking LEXP- $\forall_{\text {loose }} \gg \operatorname{LEX}(V$, gender) holds only by stipulation; nothing prevents a minimally different language, French', from having the opposite ranking. If so, the grammar of French' will productively mix features of suppletive masculine and feminine adjectival forms to create the impossible liaison realizations in (40).

\footnotetext{
14 Although this analysis makes no direct provision for lexical irregularity, data like (39) could presumably be accommodated by according a greater role to token frequency, relaxing the assumption that, in all cases, the masculine and feminine citation forms are stored in memory while the liaison form is derived phonologically: see note 11 above.
} 


\begin{tabular}{|c|c|c|c|c|}
\hline & & M.SG citation & F.SG citation & M.SG liaison \\
\hline beau & 'beautiful' & bo & bel & *bol \\
\hline nouveau & 'new' & nuvo & nuvel & *nuvol \\
\hline vieux & 'old' & vjø & vjcj & $*_{\text {vjøj }}$ \\
\hline fou & 'crazy' & fu & fol & ${ }^{*}$ ful \\
\hline mou & 'soft' & $\mathrm{mu}$ & $\mathrm{mol}$ & ${ }^{*}$ mul \\
\hline
\end{tabular}

This is a very serious problem: the theory of LEX constraints turns out to predict the existence of grammars that generate new allomorphs automatically and deterministically by blending submorphic phonological properties from different cells in suppletive paradigms, contrary to (24). Yet suppletive blending is at best a sporadic phenomenon; it is not known ever to apply regularly. More generally, the blending of submorphic properties is at best a highly peripheral mechanism of morphophonological innovation. The true engines of morphophonological change are morphological and phonological reanalysis: morphological reanalysis involves the recutting (Diertani 2011) and redistribution of morphs; phonological reanalysis involves the restructuring of phonological input representations, leading to wellunderstood phenomena such as domain narrowing, rule scattering, morphologization, and lexicalization (Bermúdez-Otero \& Trousdale 2012: §2; Bermúdez-Otero 2015: §2.3; Ramsammy 2015). As shown in (23), frameworks incorporating underlying representations avoid the suppletive blending pathology: the submorphic properties of suppletive exponents do not mix because, by definition, suppletive exponents are not subsumed under a single underlier.

In sum, both the masculine and feminine citation forms of a French adjective play a crucial role in determining the adjective's behaviour in prenominal liaison. This role is best understood as taking effect during the discovery of underlying representations. This explains why the generation of split-base liaison forms always involves productive phonological processes and why split-base liaison shows lexical irregularity. In combination with an autosegmental approach to latent consonants, moreover, this analysis predicts the behaviour of liaison forms before intonational phrase boundaries with striking elegance and accuracy. In contrast, theoretical frameworks in which the computation of the liaison form refers directly to the surface realizations of the masculine and feminine incur the suppletive blending pathology. These results indicate that the facts of French adjectival liaison are perfectly consistent with Cyclic Containment.

\section{Romanian morphological palatalization}

\subsection{The problem of inflection dependence in Romanian palatalization}

Steriade (2008) launched a further challenge to Cyclic Containment (1) with evidence from palatalization in Romanian; here I focus on her arguments from the behaviour of the velar stops $/ \mathrm{k}, \mathrm{g} /$. According to Chitoran (2001: 184ff), Romanian velar plosives are subject to two separate palatalization processes: one, which Chitoran calls 'phonological', applies across the board before front vocoids and yields stops with a secondary articulation, i.e. [ki, gi]; the other, which she calls 'morphological', applies 
before $/ \mathrm{i}, \mathrm{e} /$ in certain morphological environments and generates palatoalveolar affricates, i.e. [t $\mathrm{f}, \mathrm{d}]{ }^{15}$ Steriade's argument concerns the latter process. Morphological palatalization is perfectly systematic before the inflectional suffixes /-i/ and /-e/: the former, usually surfacing as desyllabified [i], marks second person singular in verbs, and plural number in a large subset of nouns and adjectives, including all masculine forms; the latter marks third person singular in certain verbs, and plural number in some feminine and neuter nouns and adjectives. ${ }^{16}$

\begin{tabular}{|c|c|c|c|c|}
\hline a. rák & M.SG & rátfi & M.PL & 'crayfish' \\
\hline fák & 1SG.IND & fátji & 2SG.IND & 'do’' \\
\hline mág & M.SG & mádzi & M.PL & 'magus' \\
\hline súg & 1SG.IND & súdzi & 2SG.IND & 'suck' \\
\hline b. fiikn & F.SG & fiitfe & F.PL & 'daughter' \\
\hline fákı & 3SG.SBJV & fátfe & 3SG.IND & 'do’' \\
\hline álg $\Lambda$ & F.SG & áldze & F.PL & 'seaweed' \\
\hline $\operatorname{súg}_{\Lambda}$ & 3SG.SBJV & súdze & 3SG.IND & 'suck' \\
\hline
\end{tabular}

(Chitoran 2001: 187, Steriade 2008: 318)

Steriade observes that a stem-final $/ \mathrm{k} /$ or $/ \mathrm{g} /$ becomes $[\mathrm{g}]$ or $[\mathrm{d}]$ ] before derivational suffixes beginning with $/ \mathrm{i} /$ only if the consonant is subject to regular morphological palatalization before the marker /-i/ or /-e/ in the stem's inflectional paradigm. Thus, the derivational suffix /-ist/ causes palatalization only in base nouns with plurals in /-i/ or /-e/; base nouns with plurals of other types resist palatalization: cf. $(42, \mathrm{a})$ and $(42, \mathrm{~b})$. In denominal verb formation, in turn, nouns with plurals in $/-\mathrm{i} /$ or /-e/ preferentially combine their palatalized stem allomorphs with the default verbalizer /-i/; other nouns, in contrast, select less frequent verbalizers, like /-á/ or /-uí/, whose initial vowels are nonpalatalizing: cf. $(42, c)$ and $(42, d)$.

$$
\text { base }
$$

\section{derivative}

a. SG sting $\Lambda$

PL stindzi 'left (hand)'

b. SG fók

PL fókuri 'fire'

'leftist'

'locomotive engineer'

\footnotetext{
15 Other consonants undergo morphological palatalization in the same grammatical environments as the velar plosives, but only before /i/. The results differ from consonant to consonant: e.g. [p] [pii], [b] [bii], [t] [tsi], [d] [zi], [s] [ [ji], [z] [3i], etc. See Chitoran (2001: 186-9) for details.

16 As well as in /-i/ and /-e/, plural nouns may end in /-ur-i/; but masculines always take /-i/. There are also some irregular plurals, e.g. SG [káp] PL [kápete] 'head', and a marker/-1-e/ used only with nouns ending in a stressed vowel, e.g. SG [steáa PL [stéle] 'star' (Chitoran 2001: 40-1; Steriade 2008: 342). In the feminine declensions, the genitive and dative singular are syncretic with the plural, except in feminine nouns with plurals in /-ur-i/ (Steriade 2008: 316-7, 345).
} 

c. SG kolák
PL kolátji 'bagel'
*inkolıkí
inkolıtgi 'to roll up'
d. $\quad$ SG fók
PL fókuri
'fire'
*infotgí
infoká
'to fire up'

(Steriade 2008: 321-2)

In Romanian, therefore, the behaviour of a stem-final velar stop in derivation is intimately correlated with its realization in inflection. Steriade refers to this phenomenon as 'inflection dependence'.

Crucially, Steriade regards palatalization before the plural markers /-i/ and /-e/ as a derived phonological property. Her key argument is that palatalization in this environment is perfectly systematic and productive, applying both to loanwords $(43, \mathrm{a})$ and to nonce items $(43, \mathrm{~b})$.
a. SG pfénig
PL pfénidji
< German Pfennig 'coin type'
(Steriade 2008: 318)
b. SG ftslag
PL frsladze $\sim$ frslıdzi
(nonce word)
(Steriade 2008: 326)

Nonetheless, $/ \mathrm{k} /$ and $/ \mathrm{g} /$ may resist palatalization when followed by a front vowel across a derivational boundary $(42, \mathrm{~b})$ or within the same morph $(44) .{ }^{17}$
a. kilográm 'kilogram’
kiéstije 'issue, thing'
$\left.\begin{array}{ll}\text { b. } & \text { SG } \\ \text { PL } & \text { /oki-u/ } \\ \text { oki-i } /\end{array}\right\} \rightarrow \quad[$ ókji $], *[o ́ t f i] \quad$ 'eye'

(Chitoran 2001: 178, 181; Steriade 2008: 318-9)

Accordingly, Steriade (2008: 319, 326-7) proposes that palatalization is driven by a comparative markedness constraint (McCarthy 2003) which bans sequences of a velar plosive plus a front vocoid if they are derived by morphological concatenation, but not if they are tautomorphemic. The constraint is morphologically indexed (Pater 2009) so as to penalize only sequences created by the relevant inflectional suffixes.

If palatalization were indeed a purely derived phonological property, then the pattern of inflection dependence illustrated in (42) would refute Cyclic Containment: when computing the surface representation of the derivative [stindzist], the phonology would need to consult the output realization of the stem in the plural form [stíndji], even though [stíndzi] is not a constituent of [stindzist]. In Steriade's terms, the derivation would be 'pseudocyclic'.

\footnotetext{
17 To understand the derivation of /oki-u/ in $(44, \mathrm{~b})$, note that masculine singular nouns take either an /-u/ or an /-e/ suffix; singular neuters almost all take/-u/. Word-final/u/ undergoes regular deletion except after vowels (where it surfaces as a glide) and when required for the syllabification of a consonant cluster. See Chitoran (2001: 37-9, 135-42, 173-84).
} 
However, the analysis of palatalization in Romanian plurals as a purely phonological process incurs serious theoretical costs. The failure of $/ \mathrm{k}, \mathrm{g} /$ to become $[\mathrm{t}, \mathrm{d}]$ ] before tautomorphemic / $\mathrm{i}$, e/, as in (44), must be accounted as an instance of non-derived environment blocking (NDEB); but Inkelas (2011) makes a strong case for regarding morphological NDEB as a spurious category (see also Chong 2017). Inkelas finds no instances of a phonological process that applies whenever its environment is met by virtue of morphological concatenation, and not otherwise. Rather, all putative examples of morphological NDEB appear to involve restrictions to specific constructions: once these have been enumerated, there is no work left for a derived environment condition to do. Indeed, Steriade's analysis of palatalization in plural nouns supplements comparative markedness (which captures the putative derived environment effect) with constraint indexation. The latter, however, has been criticized as compromising the empirical content, heuristic power, and learnability of linguistic theory (BermúdezOtero 2012); in the Four-Hypothesis Programme, it is explicitly banned by Indirect Reference (see Section 2). Replacing indexed constraints with less powerful devices can improve empirical coverage, as Zimmermann (2013) showed in her reanalysis of a parade example of morph-specific phonological behaviour: vowel deletion in Yine (cf. Pater 2009). There are thus good reasons for pursuing an analysis of Romanian plural palatalization in which morphology plays a larger and more direct role, in line with Chitoran's (2001: 184ff) label for this phenomenon (see also Maiden 2013 for germane discussion of palatalization in Romanian verbs).

\subsection{Morphological control of palatalization}

Clues to such an analysis may be found in the behaviour of nouns with plurals in [-ur-i], like [fók] [fók-ur-i] in $(42, \mathrm{~b})$. The key observation is that, if a noun takes /-ur-i/ in the plural, then it may also take /-ur-/ before derivational suffixes (Steriade 2008: 343):
a. base
SG vint- $(\mathrm{u})$
PL vint-ur-i
'wind'
b. derivatives

$\begin{array}{ll}\text { vint-ur-á } & \text { 'to shake in the wind' } \\ \text { vint-ur-él } & \text { 'wind.DIM' }\end{array}$

Since plurality does not enter into the computation of the meaning of the items in $(45, \mathrm{~b})$, the morph [-ur-] cannot be an exponent of number; rather, it must be analysed as an extension of the stem, i.e. as a thematic element (TH). This analysis is corroborated by diachronic evidence (Martin Maiden p.c.). The stem extension -ur-arose through the morphological recutting of the stems of Latin noun forms like corpor- $a$ 'body-N.NOM/ACC.PL' (cf. SG corpus- $\varnothing$ ). Latin or- $a$ became -ur-e in old Romanian. Subsequently, Romanian nouns with plurals in -ur-e were caught up in a more general process of morphological change whereby the plural marker $-i$ enlarged its distribution at the expense of $-e$ : e.g. roat-ă F.SG $\sim$ roat-e F.OBL.SG/F.PL > roat- $\breve{a} \sim$ rots-i 'wheel'. In nouns with plurals in -ur-e, however, innovative $-i$ replaced just $-e$, rather than the whole string $-u r-e$ : e.g. vânt-ur-e $>$ vânt-ur-i, *vânt-i 'wind.PL'. This confirms that speakers did not parse -ur-as part of the plural marker, but as part of the 
stem. Thus, Romanian nouns with plurals in $[-u r-i]$ turn out to have the morphosyntactic structure shown in (46).

a. $\quad[\operatorname{vint}(\mathrm{u})]$ 'wind.sG'

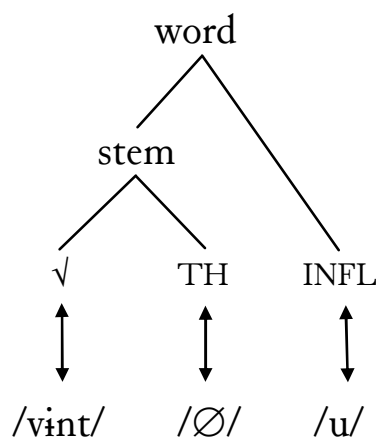

b. [v'inturi] 'wind.PL'

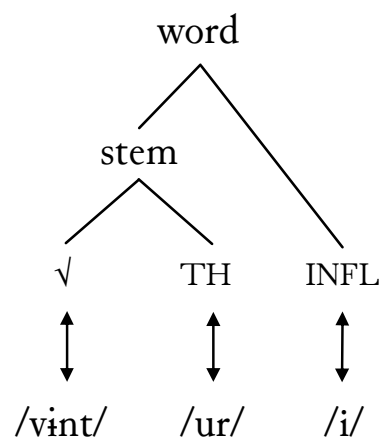

This structure is well-attested in other present-day Romance varieties: see e.g. Bermúdez-Otero (2013: 4-6) for a parallel in Spanish.

The morphological parses in (46) entail that, in nouns of this class, the thematic element has two allomorphs: /- $\varnothing-/$ and /-ur-/. Interestingly, these two allomorphs are subject to phonologically driven selection in the presence of certain derivational suffixes (Steriade 2008: 343-4). Inside the diminutive suffix /-él/, for example, /-ur-/ is chosen if its presence is required to avoid a pretonic sequence consisting of a single syllable $(47, \mathrm{a})$; otherwise, the null allomorph is selected $(47, \mathrm{~b}){ }^{18}$
a. /vint- $\left\{\begin{array}{l}\varnothing \\ \text { ur }\end{array}\right\}-$ él/
oó
*vintél
$\prec \quad \dot{\sigma} \sigma \dot{\sigma}$
$\vdots \grave{n}$
vinturél
'wind.DIM'
b. /virtez- $\left\{\begin{array}{l}\varnothing \\ \text { ur }\end{array}\right\}$-éll
virtezél
'maelstrom.DIM'

From this viewpoint, the appearance of [-ur-] inside [vinturél] does not involve pseudocyclicity; it is a simple instance of phonologically driven theme selection. The underlying representation of the noun stem contains all the information required by the phonology, and the derivation never refers to the plural form [vínturi]. The latter does of course play a crucial role in acquisition by causing the learner to set up the underlier /vint - $\{\varnothing, \mathrm{ur}\} /$. After that, however, it plays no part in the derivation.

Crucially, this approach can easily be extended to the pattern of morphological palatalization illustrated in (42). We need only assume that nouns with plurals in /-i/ and /-e/ have exactly the same morphosyntactic structure as those with plurals in /-ur-i/ (46), but select different exponents for their

\footnotetext{
18 For simplicity, (47) omits the details of the cyclic derivation. I assume that/vint- $\varnothing /$ and /vint-ur/ go through separate stem-level cycles, yielding two stem allomorphs: [vint] and [víntur]. The input to the next cycle contains a disjunction, i.e. / $\{[$ vint $],[$ vintur] $\}$ - él/, which is resolved phonologically. Spanish exhibits closely analogous cyclic domain structures: see Bermúdez-Otero (2013: 72ff) for detailed formalization.

It is interesting to note that the /-1-/ found in the plural of nouns like [stéá] [sté-1-e] 'star' (see note 16) behaves like a

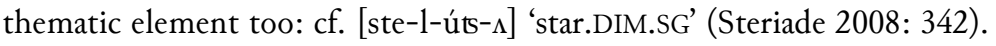


theme position: again, one exponent is null, the other overt. In the spirit of Generalized Nonlinear Affixation (Bermúdez-Otero 2012: 53), we are to envisage the overt exponent of $\mathrm{TH}$ as consisting of a floating piece of melody like (48).

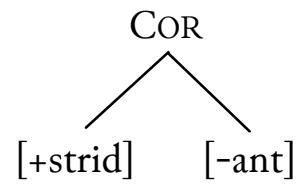

Combining the noun's root with the null exponent of $\mathrm{TH}$ results in a stem allomorph ending in a plain consonant $(49, \mathrm{a})$. In contrast, concatenating the root with the overt exponent of $\mathrm{TH}$ generates a stem allomorph subject to morphological palatalization, as the features of the thematic element seek an anchor in the root's final consonant $(49, \mathrm{~b}) .^{19}$

a. [stíngs] 'left_hand.sG'

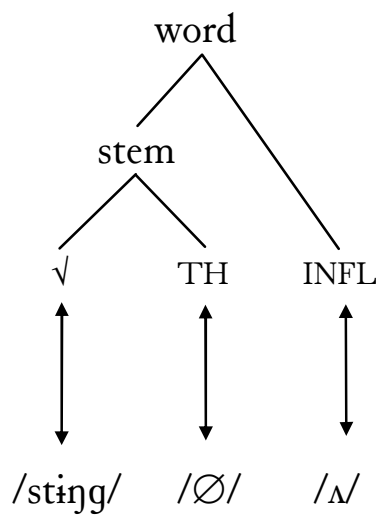

b. [stíndji] 'left_hand.PL'

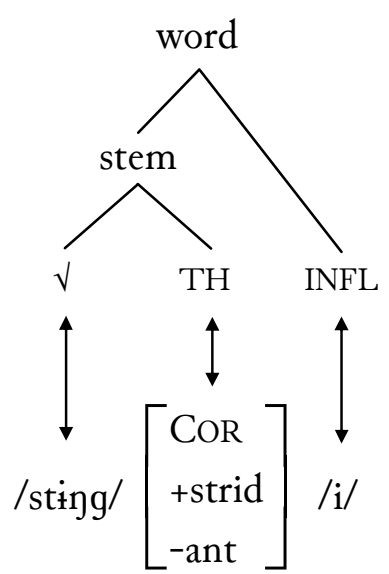

Contrasts between derivatives like [stindz-íst] 'leftist' (2,a) and [sting-át]] 'left-handed, clumsy' (Steriade 2008: 322) can now be seen to arise through phonologically driven theme selection: both forms are based on the underlying stem /sting $-\left\{\varnothing,{ }^{[\mathrm{COR},+ \text { strid,-ant }]}\right\} /$ 'left (hand)'. The derivation is analogous to that in (47).

Some of Steriade's key observations may now be interpreted as follows. In Romanian, the exponents of plural number subcategorize morphologically for stems with overt themes: ${ }^{20}$

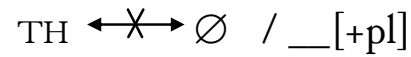

\footnotetext{
19 The docking of the floating melody will produce different results according to the feature specifications of the root's final consonant and to the ranking of markedness and faithfulness constraints (see note 15). Technical details will be highly sensitive to background assumptions about features: see for example Iosad (2012) for an approach to features that expedites the analysis of alternations similar to Romanian morphological palatalization (e.g. pp. $265 \mathrm{ff}$ ) but raises tough questions at the phonology-phonetics interface.

20 In Spanish, the plural forms of ordinary $e$-stem nouns exhibit exactly the same behaviour: see Bermúdez-Otero (2013: 11ff).
} 
In consequence, all pluralizable nouns must select a thematic element possessing an overt exponent: members of the declension classes with plurals in $[-\mathrm{i}]$ and $[-\mathrm{e}]$ choose $(51, \mathrm{a})$; most others choose $(51, \mathrm{~b})$ (see note 16).

a.

$$
\mathrm{TH} \leftrightarrow\left\{\varnothing,\left[\begin{array}{c}
\text { CoR } \\
+ \text { strid } \\
\text {-ant }
\end{array}\right]\right\}
$$

b.

$$
\mathrm{TH} \leftrightarrow\{\varnothing, \mathrm{ur}\}
$$

Otherwise, the default theme is $/-\varnothing-/$. This explains why singularia tantum, which satisfy (50) vacuously, never exhibit morphological palatalization (Steriade 2008: 345-55), as they need not abandon the default null theme for $(51, a)$. Similarly, the perfect systematicity of morphological palatalization in plural inflection, even in loanwords and nonce items (43), reflects the operation of productive processes in the morphosyntax, not in the phonology. For example, a masculine singular noun like [pfénig] can only belong to the declension that takes the suffix / $\mathrm{u} /$ in the singular and /-i/ in the plural (see notes 16 and 17), but all members of this declension systematically select theme (51,a). It therefore follows that the plural of [pfénig] must be [pfénidzi].

\subsection{Phonotactically controlled phonological properties do not exhibit inflection dependence}

The fact that an approach based on theme selection looks prima facie feasible for Romanian palatalization reveals a vulnerable spot in Steriade's (2008) argument against Cyclic Containment. As we saw above, the argument draws its force from the premise that palatalization before the plural markers $/-\mathrm{i} /$ and /-e/ is a derived phonological property; but the restriction of palatalization to a narrow set of morphological environments casts doubt on this claim.

The better to appreciate this point, consider an alternative scenario. Let Romanian' be a language exactly like actual Romanian, with the exception that the palatalization of $/ \mathrm{k}, \mathrm{g} / \mathrm{to}$ [t, $\mathrm{d}]$ before front vocoids applies across the board without exception within the inflectional paradigms of nouns with simple stems (i.e. stems that do not contain derivational suffixes). Thus, Romanian' exhibits all the alternations in (41), but it has [tilográm] instead of [kilográm], [téstije] instead of [kiéstije], and [ótji] instead of [ókji]; cf. (44). At the same time, Romanian' retains the correlation between plural inflection and derivation observed in (42): i.e. palatalization still goes ahead in [stindz-íst] (cf. plural [stíndz-i]), and is still blocked in [fok-íst] (cf. plural [fók-uri]).

If such a language existed, it would provide a devastating argument against Cyclic Containment. In modular cyclic frameworks like Stratal Phonology (Bermúdez-Otero 2018), a process of palatalization that applies across the board in all the inflectional wordforms of all simple stems must take the grammatical word as its cyclic domain, and so be word-level; but a word-level phonological process is predicted to apply across word-internal derivational boundaries too. In Romanian', the theme selection account of (42) would be manifestly ad hoc, in that it would arbitrarily fail to subsume the palatalization of [st'́ndzi], [ótji], and [tyilográm] under a single phonological generalization. But, significantly, Romanian' does not exist. 
Thus, the containment-compliant analysis of Romanian morphological palatalization as phonologically driven theme selection brings to light a deep link between the morphological control of palatalization in simple stems, manifested in the contrast between (41) and (44), and its apparent inflection-dependent behaviour in complex stems (42). The general prediction is stated in (52).

(52) Correlations in phonological behaviour between complex derived stems and the inflected forms of their bases involve phonological processes that exhibit morphological control also within the inflectional paradigms of simple stems.

Strikingly, this prediction is supported by evidence from Romanian itself: as expected, Romanian phonological processes found to be under pure phonotactic control in the paradigms of simple stems fail to exhibit inflection dependence in derived stems. Notably, Romanian has a rich set of alternations affecting mid vowels (Chitoran 2001: ch. 7). Of interest here is a process whereby [o] diphthongizes to [oa] under stress when followed by a non-high vowel in the next syllable (Steriade 2008: 341): $:^{21}$

$$
\begin{array}{lll}
\text { 'grave' } & \text { PL } & \text { grópi } \\
& \text { SG } & \text { groáps }
\end{array} \text { diphthongization: } 1^{\text {st }} \sigma \text { stressed, } 2^{\text {nd }} \sigma \text { headed by a [-high] vowel }
$$

Steriade observes that the [o] [oa] alternation is not inflection-dependent. Denominal verbs consistently display [o] outside the diphthongization environment. Crucially, this is true not only when the inflectional paradigm of the base noun contains a monophthongal stem allomorph (54,a), but also when the base noun shows the diphthong [oa] in all its inflected forms $(54, b)$.

$$
\text { base }
$$

derivative

a. $\quad$ SG groáps

PL grópi 'grave'

b.

SG gloátı 'mob'
PL gloáte

$\begin{array}{ll}\text { *ingroapá } & \text { 'to bury' } \\ \text { ingropá } & \\ \text { *ingloatí } & \\ \text { inglotí } & \text { 'to mob' }\end{array}$

Stratal Phonology explains this state of affairs. The distribution of [oa] is subject to two systematic restrictions in the native Romanian vocabulary: [oa] cannot occur in a stressless syllable, and it cannot occupy the final syllable in the prosodic word (Chitoran 2001: 213, Pană Dindelegan 2013: 12). ${ }^{22}$ These restrictions hold across the board in the wordforms of simple native stems, as illustrated by the following verbal paradigm (Chitoran 2001: 205):

\footnotetext{
21 This statement recapitulates the diachronic development of [oa]. For different synchronic perspectives on this alternation, see Chitoran (2001: ch. 7), Marin (2007), and Renwick (2012).

22 Unstressed [oa] occurs in loanwords from French like $t$ [oa] létă 'lavatory' (French toilette) and $p$ [oa] nsón 'hole punch' (French poinçon). Note, however, that toaletă has developed a nonstandard nativized pronunciation with hiatus: $t[$ o.a] letă
} 


\begin{tabular}{|c|c|c|c|c|}
\hline ‘sleep’ & & & SG & PL \\
\hline & IND & 1 & dórm & dor.mím \\
\hline & & 2 & dórmi & dor.mítsi \\
\hline & & 3 & doár.me & dórm \\
\hline & SBJV & 3 & 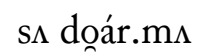 & sı doár.m \\
\hline
\end{tabular}

The ban on unstressed [oa] thus proves to be a true word-level phonotactic constraint on the native lexicon, quite unlike morphological palatalization. But native derived stems-or rather their inflected forms - go through the word-level phonology just like simple stems. It therefore follows that derivatives like [inglotí] will show monophthongal [o] in unstressed syllables, even if the base noun displays [oa] throughout its paradigm. In contrast, a theory that describes inflection dependence pseudocyclically by means of LEX constraints overgenerates: it can describe a language, Romanian", where [inglotí] loses to *[ingloatí] or *[ingloatá] owing to a top-ranked constraint forbidding the occurrence of [o] in a derivative unless [o] surfaces in some inflectional form of the base. Like Romanian', however, Romanian" does not exist, and for the same reason.

I conclude that the facts of Romanian not only comply with, but in fact support, Cyclic Containment.

\section{Conclusion}

Many critiques of underlying representations (Burzio 1996, Cole \& Hualde 1998, Allen \& Becker 2015) raise entirely legitimate questions: if all the information encoded in underliers can be inferred from paradigmatic relations between surface forms, why assume that learners go through the trouble of setting up underlying representations in the first place? why not use surface-to-surface computation instead of derivations from underliers? Such questions are lent particular urgency by doubts about the learnability of underlying representations (Becker 2015), although recent years have witnessed a great deal of progress in this area (Cotterell et al. 2015, O'Hara 2017, Rasin et al. 2017). Yet the fundamental issue remains: what explanatory work do underlying representations do for us?

This article has shown that, in fact, underlying representations perform an indispensable role in the architecture of grammar: they define the boundary between regular phonology on the one hand, and suppletive allomorphy and morphologically controlled distribution on the other. This modular demarcation of phonology from morphology turns out to explain key empirical facts about phonological paradigmatic dependencies in natural language. The evidence of Latin rhotacism in Section 3 and of French adjectival liaison in Section 4 has demonstrated that phonological paradigmatic dependencies can be systematically extended to new items if they involve regular alternation, but not if they involve suppletive allomorphy (4). Conversely, the evidence of Romanian in Section 5 showed that, when a

(Renwick 2012: 114). Thus, the incidence of unstressed [oa] differs qualitatively from that of nonpalatalized [kji] and [kje]: as we saw in (44), the latter occur freely in high-frequency patrimonial words like [ókij] 'eye(s)' and [kiéstije] 'issue, thing'. 
phonological property is diagnosed as being under pure phonotactic control across the inflectional paradigms of simple items, its distribution in complex items will not show sensitivity to the paradigmatic properties of their bases (52).

Frameworks relying on surface-to-surface computation fail to recover these predictions because they are inherently nonmodular. As a result, they are forced to give up the distinction between regular alternation and suppletive allomorphy. This is replaced with alternative criteria such as the confidence or salience of morphophonological patterns. Yet these criteria are not up to the task: the case of Latin opus operis vs acer aceris in Section 3 showed that patterns of suppletive allomorphy can enjoy high confidence, but they will not be systematically extended to new items.

Until theories of surface-to-surface computation address these problems, we have good reason to retain underlying representations in the context of modular cyclic architectures of grammar.

\section{Acknowledgements}

Earlier versions of this paper were presented at conferences and seminars in Bloomington, Cambridge, Jerusalem, Leipzig, London, Oxford, Paris, Tours, and Tromsø. I am grateful to the audiences on all these occasions for their questions and comments. I have also benefited from observations and suggestions from Ioana Chitoran, Jacques Durand, Pavel Iosad, Martin Maiden, Stefania Marin, Tobias Scheer, Ranjan Sen, Donca Steriade, and Leo Wetzels, and from discussions in student work by Jack Rodber and Donald Morrison. I alone am responsible for all errors and omissions.

\section{References}

Albright, Adam. 2002. The identification of bases in morphological paradigms. Los Angeles: Doctoral dissertation, UCLA.

Albright, Adam. 2008. Explaining universal tendencies and language particulars in analogical change. In Jeff Good (ed.), Linguistic universals and language change, 144-181. Oxford: Oxford University Press.

Albright, Adam \& Bruce Hayes. 2003. Rules vs. analogy in English past tenses: a computational/experimental study. Cognition 90 (2), 119-161.

Allen, Blake \& Michael Becker. 2015. Learning alternations from surface forms with sublexical phonology. Ms, University of British Columbia and Stony Brook University. Available at http://ling.auf.net/lingbuzz/002503.

Anderson, Stephen R. 1992. A-morphous morphology. Cambridge: Cambridge University Press.

Bailyn, John F. \& Andrew Nevins. 2008. Russian genitive plurals are impostors. In Asaf Bachrach \& Andrew Nevins (eds.), Inflectional identity, 237-270. Oxford: Oxford University Press.

Baldi, Philip. 1994. Some thoughts on Latin rhotacism. General Linguistics 34, 209-216.

Becker, Michael. 2015. MaxEnt as a baseline theory of grammar. Paper presented at 'W(h)ither OT?', $m f m$ fringe workshop, Manchester, 27 May 2015.

Benua, Laura. 1997. Transderivational identity: phonological relations between words. Amherst, MA: Doctoral dissertation, University of Massachusetts.

Bermúdez-Otero, Ricardo. 2010. Stratal Optimality Theory: an overview. http://www.bermudezotero.com/Stratal_Optimality_Theory.htm. 
Bermúdez-Otero, Ricardo. 2012. The architecture of grammar and the division of labour in exponence. In Jochen Trommer (ed.), The morphology and phonology of exponence (Oxford Studies in Theoretical Linguistics 41), 8-83. Oxford: Oxford University Press.

Bermúdez-Otero, Ricardo. 2013. The Spanish lexicon stores stems with theme vowels, not roots with inflectional class features. Probus 25 (1), 3-103.

Bermúdez-Otero, Ricardo. 2015. Amphichronic explanation and the life cycle of phonological processes. In Patrick Honeybone \& Joseph C. Salmons (eds.), The Oxford bandbook of historical phonology, 374-399. Oxford: Oxford University Press.

Bermúdez-Otero, Ricardo. 2018. Stratal Phonology. In S.J. Hannahs \& Anna R. K. Bosch (eds.), The Routledge bandbook of phonological theory, 100-134. Abingdon: Routledge.

Bermúdez-Otero, Ricardo \& Richard M. Hogg. 2003. The actuation problem in Optimality Theory: phonologization, rule inversion, and rule loss. In D. Eric Holt (ed.), Optimality Theory and language change, 91-119. Dordrecht: Kluwer.

Bermúdez-Otero, Ricardo \& Graeme Trousdale. 2012. Cycles and continua: on unidirectionality and gradualness in language change. In Terttu Nevalainen \& Elizabeth Closs Traugott (eds.), The Oxford bandbook of the bistory of English, 691-720. New York: Oxford University Press.

Blevins, James P. 2006. Word-based morphology. Journal of Linguistics 42, 531-573.

Bonami, Olivier \& Gilles Boyé. 2003. La nature morphologique des allomorphies conditionnées: les formes de liaison des adjectifs en français. In Bernard Fradin et al. (eds.), Les unités morphologiques (Silexicales 3), 39-48. Lille: Laboratoire STL (Savoirs, Textes, Langage), UMR 8163 (CNRS, Universités de Lille 3 et de Lille 1).

Bowers, Dustin. 2015. A system for morphophonological learning and its consequences for language change. Los Angeles: Doctoral dissertation, UCLA.

Burzio, Luigi. 1996. Surface constraints versus underlying representation. In Jacques Durand \& Bernard Laks (eds.), Current trends in phonology: models and methods, vol. 1, 123-141. Salford: European Studies Research Institute, University of Salford.

Chitoran, Ioana. 2001. The phonology of Romanian: a constraint-based approach (Studies in Generative Grammar 56). Berlin: Mouton de Gruyter.

Chomsky, Noam \& Morris Halle. 1968. The sound pattern of English. New York: Harper \& Row.

Chong, Junxiang Adam. 2017. On the relation between phonotactic learning and alternation learning. Los Angeles: Doctoral dissertation, UCLA.

Côté, Marie-Hélène. 2010. Le statut des consonnes de liaison: l'apport de données du français laurentien. In Franck Neveu et al. (eds.), CMLF 2010 - 2ème Congrès Mondial de Linguistique Française. Paris: Institut de Linguistique Française.

Côté, Marie-Hélène. 2011. French liaison. In Marc van Oostendorp, Colin J. Ewen, Elizabeth Hume \& Keren Rice (eds.), The Blackwell companion to phonology, vol. 5: Phonological across languages, 2685-2710. Malden, MA: Wiley-Blackwell.

Cotterell, Ryan, Nanyun Peng \& Jason Eisner. 2015. Modeling word forms using latent underlying morphs and phonology. Transactions of the Association for Computational Linguistics 3, 433-447.

Diertani, Chaya Eliana Ariel. 2011. Morpheme boundaries and structural change: affixes running amok. Philadelphia: Doctoral dissertation, University of Pennsylvania.

Durand, Jacques. 2014. Corpora, variation and phonology: an illustration from French liaison. In Jacques Durand, Ulrike Gutt \& Gjert Kristoffersen (eds.), The Oxford handbook of corpus phonology, 240-264. Oxford: Oxford University Press. 
Durand, Jacques \& Julien Eychenne. 2014. Mot et phonologie en français: de la persistance d'une illusion. In Jacques Durand, Gjert Kristoffersen \& Bernard Laks (eds.), La phonologie du français: normes, périphéries, modélisation, 227-260. Paris: Presses Universitaires de Paris Ouest.

Durand, Jacques \& Chantal Lyche. 2004. Structure et variation dans quelques systèmes vocaliques du français: l'enquête Phonologie du français contemporain (PFC). In A. Coveney \& C. Sanders (eds.), Variation et francophonie, 217-240. Paris: L'Harmattan.

Durand, Jacques \& Chantal Lyche. 2008. French liaison in the light of corpus data. Journal of French Language Studies 18 (01), 33-66.

Embick, David. 2010. Localism versus globalism in morphology and phonology (Linguistic Inquiry Monographs 60). Cambridge, MA: The MIT Press.

Embick, David \& Morris Halle. 2005. On the status of stems in morphological theory. In Twan Geerts, Ivo van Ginneken \& Haike Jacobs (eds.), Romance languages and linguistic theory 2003: selected papers from 'Going Romance' 2003, Nijmegen, 20-22 November (Current Issues in Linguistic Theory 270), 37-62. Amsterdam: John Benjamins.

Féry, Caroline. 2004. Liaison and syllable structure in French. Ms, University of Potsdam. Available at http://web.uni-frankfurt.de/fb10/fery/publications/Liaison_and_syllable_structure_in_French.pdf.

Grevisse, Maurice \& André Gosse. 2011. Le bon usage, $15^{\text {th }}$ edn. Paris: De Boeck.

Halle, Morris \& Alec Marantz. 1993. Distributed Morphology and the pieces of inflection. In Kenneth Hale \& Samuel Jay Keyser (eds.), The view from Building 20: essays in linguistics in bonor of Sylvain Bromberger, 111-176. Cambridge, MA: MIT Press.

Hannahs, S.J. 1995. Prosodic structure and French morphophonology. Tübingen: Niemeyer.

Haugen, Jason D. 2016. Readjustment: rejected? In Daniel Siddiqi \& Heidi Harley (eds.), Morphological metatheory (Linguistics Today 229), 303 - 342. Amsterdam: John Benjamins.

Hyman, Larry M. 2018. Why underlying representations? Journal of Linguistics.

Inkelas, Sharon. 1998. The theoretical status of morphologically conditioned phonology: a case study of dominance effects. In Geert Booij \& Jaap van Merle (eds.), Yearbook of Morphology 1997, 121-155. Dordrecht: Kluwer.

Inkelas, Sharon. 2011. Another look at velar deletion in Turkish, with special attention to the derived environment condition. In Eser Erguvanlı Taylan \& Bengisu Rona (eds.), Puzzles of language: essays in bonour of Karl Zimmer (Turcologica 86). Wiesbaden: Harrassowitz Verlag.

Inkelas, Sharon. 2012. The morphology-phonology connection. In Sarah Berson et al. (eds.), Proceedings of the Thirty-Fourth Annual Meeting of the Berkeley Linguistics Society, 145-162. Berkeley, CA: Berkeley Linguistics Society.

Inkelas, Sharon \& Cheryl Zoll. 2007. Is grammar dependence real? A comparison between cophonological and indexed constraint approaches to morphologically conditioned phonology. Linguistics 45 (1), 133-171.

Iosad, Pavel. 2012. Representation and variation in substance-free phonology: a case study in Celtic. Doctoral dissertation, Center for Advanced Study in Theoretical Linguistics, University of Tromsø.

Kenstowicz, Michael. 1996. Base-identity and uniform exponence: alternatives to cyclicity. In Jacques Durand \& Bernard Laks (eds.), Currents trends in phonology: models and methods, vol. 1, 363-393. Salford: European Studies Research Institute, University of Salford.

Kenstowicz, Michael \& Charles Kisseberth. 1977. Topics in phonological theory. New York: Academic Press. Kiparsky, Paul. 1982. Lexical Morphology and Phonology. In In-Seok Yang for the Linguistic Society of Korea (ed.), Linguistics in the morning calm: selected papers from SICOL-1981, vol. 1, 3-91. Seoul: Hanshin Publishing Company. 
Kiparsky, Paul. 1997. Covert generalization. In Geert Booij, Angela Ralli \& Sergio Scalise (eds.), Proceedings of the First Mediterranean Conference of Morphology (Mytilene, Greece, Sept. 19-21 1997), 65-76. University of Patras.

Kiparsky, Paul. 2000. Opacity and cyclicity. The Linguistic Review 17 (2-4), 351-365.

Kiparsky, Paul. 2015. Stratal OT: a synopsis and FAQs. In Yuchau E. Hsiao \& Lian-Hee Wee (eds.), Capturing phonological shades within and across languages, 2-44. Newcastle upon Tyne: Cambridge Scholars Publishing.

Lamarche, Jacques. 1996. Gender agreement and suppletion in French. In Karen Zagona (ed.), Grammatical theory and Romance languages: selected papers from the $25^{\text {th }}$ Linguistic Symposium on Romance Languages (LSRL XXV), Seattle, 2-4 March 1995 (Current Issues in Linguistic Theory 13), 145-157. Amsterdam: John Benjamins.

Maiden, Martin. 2013. 'Semi-autonomous' morphology? A problem in the history of the Italian (and Romanian) verb. In Silvio Cruschina, Martin Maiden \& John Charles Smith (eds.), The boundaries of pure morphology: diachronic and synchronic perspectives (Oxford Studies in Diachronic and Historical Linguistics 4), 24-44. Oxford: Oxford University Press.

Marin, Stefania. 2007. Vowel to vowel coordination, diphthongs and Articulatory Phonology. Doctoral dissertation, Yale University.

McCarthy, John J. 2003. Comparative markedness. Theoretical Linguistics 29, 1-51.

Morin, Yves-Charles. 1986. On the morphologization of word-final consonant deletion in French. In Henning Andersen (ed.), Sandhi phenomena in the languages of Europe, 167-210. Berlin: Mouton de Gruyter.

Morin, Yves-Charles. 2005. La liaison relève-t-elle d'une tendance à éviter les hiatus? Réflexions sur son évolution historique. Langages 158, 8-23.

Morin, Yves-Charles \& Jonathan D. Kaye. 1982. The syntactic bases for French liaison. Journal of Linguistics 18 (2), 291-330.

Nevins, Andrew \& Bert Vaux. 2008. Underlying representations that do not minimize grammatical violations. In Sylvia Blaho, Patrik Bye \& Martin Krämer (eds.), Freedom of analysis, 35-61. Berlin: Mouton de Gruyter.

Nguyen, Noël \& Zsuzsanna Fagyal. 2008. Acoustic aspects of vowel harmony in French. Journal of Phonetics 36 (1), 1-27.

O'Hara, Charlie. 2017. How abstract is more abstract? Learning abstract underlying representations. Phonology $34,325-345$.

Orgun, Cemil Orhan. 1996. Sign-based morphology and phonology with special attention to Optimality Theory. Berkeley, CA: Doctoral dissertation, University of California, Berkeley.

Pană Dindelegan, Gabriela (ed.) 2013. The grammar of Romanian. Oxford: Oxford University Press.

Pater, Joe. 2009. Morpheme-specific phonology: constraint indexation and inconsistency resolution. In Steve Parker (ed.), Phonological argumentation: essays on evidence and motivation (Advances in Optimality Theory), 123-154. London: Equinox Publishing.

Perlmutter, David. 1998. Interfaces: explanation of allomorphy and the architecture of grammars. In Steven G. Lapointe, Diane K. Brentari \& Patrick M. Farrell (eds.), Morphology and its relation to phonology and syntax, 307-338. Stanford, CA: CSLI Publications.

Plénat, Marc. 2008. La liaison "obligatoire” avec et sans enchaînement. In Jacques Durand, Benoît Habert \& Bernard Laks (eds.), Congrès mondial de linguistique française CMLF-2008, 1657-1667. Paris: Institut de Linguistique Française et EDP Sciences.

Ramsammy, Michael. 2015. The life cycle of phonological processes: accounting for dialectal microtypologies. Language and Linguistics and Language Compass 9 (1), 33-54. 
Rasin, Ezer, Iddo Berger, Nur Lan \& Roni Katzir. 2017. Learning rule-based morpho-phonology. Ms, MIT and Tel Aviv University. http://ling.auf.net/lingbuzz/003665 (accessed on 13 September 2017).

Renwick, Margaret. 2012. Vowels of Romanian: historical, phonological and phonetic studies. Doctoral dissertation, Cornell University.

Roberts, Philip J. 2012. Latin rhotacism: a case study in the life cycle of phonological processes. Transactions of the Pbilological Society 110 (1), 80-93.

Rodber, Jack A. 2008. Explaning the analogical levelling of the Latin bonor paradigm. MA dissertation, University of Manchester.

Saussure, Ferdinand de. 1916. Cours de linguistique générale (ed. by Charles Bally and Albert Sechehaye, in collaboration with Albert Reidlinger). Lausanne and Paris: Librairie Payot.

Scheer, Tobias. 2011. A guide to morphosyntax-phonology interface theories: how extra-phonological information is treated in phonology since Trubetzkoy's Grenzsignale. Berlin: Mouton de Gruyter.

Smolensky, Paul \& Matthew Goldrick. 2016. Gradient symbolic representations in grammar: the case of French liaison. Ms, Johns Hopkins University and Northwestern University. Available as ROA 1286 at the Rutgers Optimality Archive, http://roa.rutgers.edu.

Steriade, Donca. 1999. Lexical conservatism in French adjectival liaison. In J.-Marc Authier, Barbara E. Bullock \& Lisa Reid (eds.), Formal perspectives on Romance linguistics: selected papers from the $28^{\text {th }}$ Linguistic Symposium on Romance languages (LSRL XXVIII), University Park, 16-19 April 1998 (Current Issues in Linguistic Theory 185), 243-270. Amsterdam: John Benjamins.

Steriade, Donca. 2008. A pseudo-cyclic effect in Romanian morphophonology. In Asaf Bachrach \& Andrew Nevins (eds.), Inflectional identity (Oxford Studies in Theoretical Linguistics 18), 313-359. Oxford: Oxford University Press.

Steriade, Donca. 2012. The cycle without containment: Latin perfect stems. Ms, MIT. http://lingphil.mit.edu/papers/steriade/Steriade2012LatinPerfect.pdf.

Steriade, Donca. 2013. The cycle without containment: Romanian perfect stems. Paper presented at the $21^{\text {st }}$ Manchester Phonology Meeting, Manchester, 25 May 2013.

Steriade, Donca \& Igor Yanovich. 2015. Accentual allomorphs in East Slavic: an argument for inflection dependence. In Eulàlia Bonet, Maria-Rosa Lloret \& Joan Mascaró (eds.), Understanding allomorphy: perspectives from Optimality Theory (Advances in Optimality Theory), 254-313. Sheffield: Equinox.

Stonham, John T. 1994. Combinatorial morphology (Current Issues in Linguistic Theory 120). Amsterdam: John Benjamins.

Stump, Gregory T. \& Raphael A. Finkel. 2013. Morphological typology: from word to paradigm. Cambridge: Cambridge University Press.

Tranel, Bernard. 1981. Concreteness in generative phonology: evidence from French. Berkeley: University of California Press.

Tranel, Bernard. 1988. A propos de l'ajustement de E en français. In S. Paul Verluyten (ed.), La phonologie du schwa français, 89-131. Amsterdam: John Benjamins.

Tranel, Bernard. 1990. On suppletion and French liaison. Probus 2, 169-208.

Tranel, Bernard. 1995. French final consonants and nonlinear phonology. Lingua, 131-167.

Tranel, Bernard. 1996. French liaison and elision revisited: A unified account within Optimality Theory. In Claudia Parodi, Carlos Quicoli, Mario Saltarelli \& María Luisa Zubizarreta (eds.), Aspects of Romance linguistics: selected papers from the Linguistic Symposium on Romance Languages XXIV, March 10-13, 1994, 433-455. Washington, DC: Georgetown University Press. 
Trommer, Jochen. 2011. Phonological aspects of Western Nilotic mutation morphology. Habilitationsschrift, Institut für Linguistik, Universität Leipzig. Available at http://www.unileipzig.de/jtrommer/papers/WesternNiloticMutation.pdf.

Trommer, Jochen. 2015. Moraic affixes and morphological colors in Dinka. Linguistic Inquiry 46 (1), 77-112.

Valdman, Albert. 1972. The loi de position as a pedagogical norm. In Albert Valdman (ed.), Papers in linguistics and phonetics to the memory of Pierre Delattre, 409-416. The Hague: Mouton.

Weiss, Michael. 2009. Outline of the historical and comparative grammar of Latin. Ann Arbor, MI: Beech Stave Press.

Wetzels, Leo. 1981. Analogie et lexique: le problème de l'opacité en phonologie générative. Doctoral dissertation, University of Nijmegen.

Wetzels, Leo. 1987. The timing of latent consonants in Modern French. In Carol Neidle \& Rafael NúñezCedeño (eds.), Studies in Romance languages, 283-317. Dordrecht: Foris.

Wetzels, Leo. 2002. Les adjectifs pré-nominaux du français: formes longues et formes féminines. In Haike Jacobs \& Leo Wetzels (eds.), Liber amicorum Bernard Bichakjian, 273-306. Maastricht: Shaker Publications.

Wunderlich, Dieter. 2003. A minimalist view on inflectional paradigms: the expression of person and number in subjects and objects. Paper presented at the workshop 'Inflectional paradigms: primitives and structures', Institut für Deutsche Sprache, Mannheim, 24 May 2003. Available at http://web.phil-fak.uniduesseldorf.de/ $\sim$ wdl/min-view2.pdf.

Zimmermann, Eva. 2013. Vowel deletion as mora usurpation: the case of Yine. Phonology 30 (1), 125-163. 